\title{
Cultivable gut bacteria provide a pathway for adaptation of Chrysolina herbacea to Mentha aquatica volatiles
}

\author{
Graziano Pizzolante ${ }^{1 \dagger}$, Chiara Cordero ${ }^{2 \dagger}$, Salvatore M. Tredici', Davide Vergara ${ }^{1}$, Paola Pontieri $^{3}$, Luigi Del Giudice ${ }^{3}$, \\ Andrea Capuzzo ${ }^{4}$, Patrizia Rubiolo ${ }^{2}$, Chidananda N. Kanchiswamy ${ }^{5}$, Simon A. Zebelo ${ }^{6}$, Carlo Bicchi ${ }^{2}$, \\ Massimo E. Maffei ${ }^{4^{*}}$ and Pietro Alifano ${ }^{1 *}$ (D)
}

\begin{abstract}
Background: A chemical cross-talk between plants and insects is required in order to achieve a successful coadaptation. In response to herbivory, plants produce specific compounds, and feeding insects respond adequately 7 to molecules produced by plants. Here we show the role of the gut microbial community of the mint beetle Chrysolina herbacea in the chemical cross-talk with Mentha aquatica (or watermint).

Results: By using two-dimensional gas chromatography-mass spectrometry we first evaluated the chemical patterns of both $M$. aquatica leaf and frass volatiles extracted by C. herbacea males and females feeding on plants, and observed marked differences between males and females volatiles. The sex-specific chemical pattern of the frass paralleled with sex-specific distribution of cultivable gut bacteria. Indeed, all isolated gut bacteria from females belonged to either $a$ - or $\gamma$-Proteobacteria, whilst those from males were $\gamma$-Proteobacteria or Firmicutes. We then demonstrated that five Serratia marcescens strains from females possessed antibacterial activity against bacteria from males belonging to Firmicutes suggesting competition by production of antimicrobial compounds. By in vitro experiments, we lastly showed that the microbial communities from the two sexes were associated to specific metabolic patterns with respect to their ability to biotransform $M$. aquatica terpenoids, and metabolize them into an array of compounds with possible pheromone activity.
\end{abstract}

Conclusions: Our data suggest that cultivable gut bacteria of Chrysolina herbacea males and females influence the volatile blend of herbivory induced Mentha aquatica volatiles in a sex-specific way.

Keywords: Mentha aquatica, Chrysolina herbacea, Terpenoids, Insect pheromones, Gut microbial community, Microbial organic volatile compounds, Antimicrobial compounds

\section{Background}

During the long course of evolution, plants have evolved a wide range of defense mechanisms against herbivores that can be divided into two main categories: preformed constitutive defenses and inducible defenses [1]. Physical and chemical barriers existing before insect attack are used as constitutive defenses, whereas direct

\footnotetext{
* Correspondence: massimo.maffei@unito.it; pietro.alifano@unisalento.it ${ }^{\dagger}$ Equal contributors

${ }^{4}$ Dipartimento di Scienze della Vita e Biologia dei Sistemi, Università di Torino, Via Quarello 15/A, 10135 Torino, Italy

${ }^{1}$ Department of Biological and Environmental Sciences and Technologies,

University of Salento, via Monteroni 165, 73100 Lecce, Italy

Full list of author information is available at the end of the article
}

and indirect defenses are induced defenses that are triggered by the insect attack. Direct defenses are plant traits able to directly interfere with attacking insects, whereas indirect defenses comprise plant traits that do not affect the susceptibility of host plants by themselves, but can serve as attractants to natural enemies of attacking insects [2-7]. The response of insects to plant defenses includes the selective choice of different feeding sites, the alteration of the feeding rate or the induction of physiological/detoxification enzymes [8].

Plants that accumulate specialized metabolites like the aromatic plant Mentha aquatica deter herbivory with a direct defense mechanism, by producing constitutively 
terpenoids in glandular trichomes, which are specialized secretory tissues [5]. Despite the toxic content of such secretory structures, specialized herbivores not only feed on plants bearing these structures, but also have evolved the ability to recognize and being attracted by specific compounds. This kind of feeding adaptation has been described for several insect species [9]. Therefore, interactions between these insects and their host plants occasionally can lead to highly specific relationships, as in the case of M. aquatica and Chrysolina herbacea.

As demonstrated by Zebelo et al. [10], emission of volatile compounds from the glandular trichomes of $M$. aquatica is mainly characterized by the presence of the monoterpene pulegone. The pulegone, which is the major compound occurring in healthy undamaged leaves, revealed to be a potent attractant to C. herbacea, as shown by olfactometry bioassays. The plant response to C. herbacea herbivory was the activation of genes for terpenoid biosynthesis, eventually diverting most of monoterpene production from pulegone to the synthesis of menthofuran. The latter compound was found to significantly repel $C$. herbacea in bioassay tests. Despite the presence of lower amounts of many other monoterpenes, no significant difference was found in this group of molecules between infested and uninfested plants, thus confining the deterrent effect mainly to methofuran. As it is typical of plant-insect interactions, mechanical damage was not able to induce in $M$. aquatica the same response as that elicited by $C$. herbacea herbivory. Thus $C$. herbacea is attracted by pulegone produced by undamaged $M$. aquatica, but is deterred by the methofuran production by herbivore-infested $M$. aquatica. These results indicate a differential tolerance of $C$. herbacea to $M$. aquatica monoterpenes; however, the detoxifying mechanisms and the catabolic/biotransforming ability that give the insects the way to tolerate a high amount of ingested terpenoids remain an open question.

Cordero and colleagues [11], by using a combination of headspace solid-phase microextraction (HS-SPME) coupled to comprehensive two-dimensional (2D) gas chromatography combined with mass spectrometry (GCxGC-MS), analyzed the catabolic fate of monoterpenes present in some Mentha species by evaluating the terpene content of $C$. herbacea frass (faeces) after feeding on fresh leaves. The carvone-rich M. spicata L. [12], the menthol and menthone containing $M . x$ piperita L. [13], and a chemotype of M. longifolia L., particularly rich in piperitenone oxide [14] were used to demonstrate the ability of $C$. herbacea to metabolize the plant terpenoids, and the insect's amazing ability to catabolize/ biotransform them thereby producing new compounds. For instance, carvone and $Z$-carveol were detected in C. herbacea frass after feeding on $M$. $x$ piperita, a mint species that does not accumulate these two terpenes but accumulates limonene [15]. Microorganisms living in the insect intestinal tract might be involved in biotransformation of leaf volatile terpenoids [16]. Indeed, there is clear evidence of microbial transformation of limonene to $Z$-carveol and carvone [17-21]. It is known that microorganisms are able to activate catabolic and metabolic processes that are absent in insects, hence acting as "microbial brokers", a strategy that enables phytophagous insects hosting such bacteria to overcome biochemical barriers to herbivory $[22,23]$. Recently described examples are the detoxification of caffeine by gut microbes of the coffee berry borer [24], the ability of bark beetles bacterial symbionts to metabolize toxic monoterpenes and diterpene acids produced by the mountain pine beetle in response to herbivore damage [25], and the capability of the gut microbiome of cabbage root fly larvae to catalyze the conversion of the plant toxin 2-phenylethyl isothiocianate [26]. Thus, microbial degradation of plant toxic compounds can occur in insect guts and contribute to the carbon and energy requirements for the host [27].

The metabolic activity of insects feeding on plants or/ and their associated microorganisms often leads to release of oxygenated derivatives of leaf volatiles. For instance, some insects feeding on plants that, like $M$. aquatica, store 1,8-cineole, a monoterpene oxygenated compound that shows mosquito feeding deterrent and ovipositional repellent activities, and toxic effect against stored-grain beetles $[28,29]$, show a marked ability to metabolize 1,8 cineole into several hydroxyl derivatives such as 3hydroxycineol [30, 31]. As Southwell and coworkers [31] suggested, an interesting challenge would be to assess whether 1,8-cineole hydroxylation may represent either a detoxification or a metabolic strategy to produce semiochemicals. Indeed, it has been suggested that several insects, such as possums [32], Paropsisterna tigrina [33] and Leichhardt's grasshopper [34], might use hydroxycineoles as pheromonal markers. This hypothesis could extend the possible role of the microorganisms living in the insect intestinal tract, which could be involved in biosynthesis of semiochemicals.

In this study we have tested this hypothesis by characterizing the cultivable bacterial communities inhabiting the intestinal tract of $C$. herbacea female and male individuals feeding on $M$. aquatica, and then investigating the possibility that the microbial communities from the two sexes could be associated to specific metabolic patterns with respect to the ability to biotransform $M$. aquatica essential oil and release potential semiochemicals.

\section{Results}

\section{Chemical fingerprint of $M$. aquatica leaf and C. herbacea frass volatiles}

The discrimination of chemical patterns produced during the interaction between organisms represents one of 
the major challenges posed by multitrophic interactions [16, 35-38]. The chemical patterns and their contribution to metabolic interactions between $M$. aquatica, its specific herbivore $C$. herbacea and the insect microbial community were here analyzed to elucidate these multitrophic interactions. A clear chemical fingerprint of leaf and insect frass volatiles was found as reported in Table 1. GCxGC-MS analyses allowed the characterization of more than 60 compounds (including green leaf volatiles, mono- and sesquiterpenoids).

By using the dataset of Table 1, we calculated the fold change values discriminating leaf and frass components. Considering the leaf components, cis-sabinene hydrate, camphene, $\alpha$-cadinene, $\alpha$-terpinene and pulegone were more abundant in the leaf, whereas 1-octen-3-ol was particularly present in the frass volatiles (Fig. 1). On the other hand, by considering the characteristic frass compounds we found that four hydroxylated cineole derivatives and five unknown monoterpenes were almost absent in the leaf components (Fig. 2). Differences between male and female volatiles were observed in their frass extracts, with specific chemical patterns including all classes of identified volatile compounds (Fig. 3).

The highly-detailed separation patterns from frass and leaf volatiles were used as chemical signatures for a preliminary fingerprinting investigation aimed at locating informative analytes (fingerprint minutiae) whose highly variable abundance between samples (frass vs. leaf) could be considered informative of the interaction between $C$. herbacea and M. aquatica. For the preliminary processing of two-dimensional chromatograms a 'visual' features approach was used; it consists of a comparative visualization derived from an arithmetic subtraction of a sample (or analyzed) 2D-chromatogram from a reference to reveal compositional differences in the chemical pattern.

Fig. 4a shows the pseudocolor comparison of M. aquatica leaf volatiles (reference image) compared to the frass volatiles distribution from $C$. herbacea female population feeding on $M$. aquatica leaves, whereas Fig. 4b depicts the comparative visualization for C. herbacea male population volatiles. Red colorization indicates $2 \mathrm{D}$ peaks more abundant in the reference image (i.e., leaf for Figs. 4a and b) while intense green peaks refer to those more abundant in the frass analyzed chromatogram. Yellow circles in Fig. 4a and b indicate minutiae features to be investigated as potential biotransformation and/or degradation products while pink circles indicate analytes gender-specific because of their exclusive presence above the detection limit in male population. Fig. 4c shows the comparative image between frass volatiles from females (reference image) vs. those from males. In this case, the comparative visualization evidences gender-related (semi) quantitative differences between frass volatiles distribution. Light blue circles indicate 2D peaks invariant as a function of C. herbacea sex while yellow circles indicate those peaks more abundant in the reference image (i.e., female frass).

\section{Characterization of the cultivable bacterial communities of the intestinal tract of $C$. herbacea female and male individuals feeding on $M$. aquatica}

Gut microorganisms from 10 male and 10 female $C$. herbacea were isolated in pure culture by means of the standard dilution plating technique on Luria-Bertani (LB), Yeast Extract Peptone Dextrose (YEPD) and Nutrient Agar (NA) solid media. Bacterial colonies were visible after cultivation at $30{ }^{\circ} \mathrm{C}$ for $24 \mathrm{~h}$. Microbial titers from female intestines were about $10^{7}$ colony-forming units $(\mathrm{CFU}) / \mathrm{mL}$ (= per gut) on NA and LB plates, and $10^{5} \mathrm{CFU} / \mathrm{mL}$ on YEPD plates. Those from males were $10^{7} \mathrm{CFU} / \mathrm{mL}$ on LB and NA plates, while CFU on YEPD plates were about $10^{3} \mathrm{CFU} / \mathrm{mL}$. A total of 245 colonies with distinct morphology, 200 from females and 45 from males (the difference was due to fact that the colonies from females exhibited higher morphological diversity than those from males), were then isolated and examined.

All microbial isolates were preliminary grouped by using the BOX-PCR fingerprinting technique, based on the use of a single BOX-A1R primer which targets the repetitive $\mathrm{BOX}$ regions scattered in the genome of bacteria and results in strain-specific fingerprinting $[39,40]$. This technique has been successfully used to analyze the microdiversity of bacterial communities [41]. The fingerprints were composed of 8-13 major bands with sizes ranging from about 250 to $3000 \mathrm{bp}$. Repeatability of the BOX-PCR was as good as the isolates demonstrated identical profiles in three independent experiments. The results of these analyses demonstrated the presence of 10 different genomic patterns among female isolates (Additional file 1: Figure S1a, lanes 1-10) and 6 among male isolates (Additional file 1: Figure S1b, lanes 11-16).

The bacterial isolates were then identified by $16 \mathrm{~S}$ rRNA-encoding gene sequencing. The gut isolates were designed with the $\mathrm{CHF}$ or $\mathrm{CHM}$ abbreviations (for $C$. herbacea females or males, source of isolation) followed by a letter and a serial number. Molecular data highlighted that all bacterial isolates from the gut of females were $\alpha$ - or $\gamma$-Proteobacteria belonging to the following genera: Serratia (CHF-B4, CHF-B16, CHF-B17, CHF-B26, CHF-B37, CHF-G5), Pantoea (CHF-G14), Pseudomonas (CHF-PG1, CHF-PG3) and Sphingomonas (CHF-PG4). In contrast, those from males gut were $\gamma$-Proteobacteria of the genera Pseudomonas (CHM-N25, CHM-N31) and Serratia (CHM-N28) or Firmicutes belonging to the genus Bacillus (CHM-L11, CHM-L21, CHM-L22) (Table 2). 
Table 1 Quantitative descriptors of 2D peaks abundance is reported as 2D normalized volumes \% and referred to the TIC current signal; data is the mean of six biological replicates. As expected, the major leaf compound is menthofuran followed by high percentages of its precursor pulegone

\begin{tabular}{|c|c|c|c|c|c|c|c|}
\hline Compound name & 1D Rt (min) & 2D Rt (s) & $T^{T} \mathrm{~s}$ & $I^{\top}$ sTab & M. aquatica leaf & Male frass & Female frass \\
\hline (E)-2-Hexenal & 11.69 & 1.26 & 859 & 854 & 0.01 & nd & nd \\
\hline (E)-Hex-3-ene-1-ol & 11.75 & 1.64 & 860 & 851 & 0.04 & 0.06 & 0.05 \\
\hline a-Thujene & 15.42 & 0.72 & 927 & 931 & 0.27 & 0.18 & 0.20 \\
\hline a-Pinene & 15.75 & 0.76 & 933 & 939 & 1.01 & 0.38 & 0.31 \\
\hline Camphene & 16.62 & 0.8 & 949 & 953 & 0.12 & 0.01 & 0.02 \\
\hline$\beta$-Pinene & 18.02 & 0.88 & 974 & 979 & 1.35 & 0.33 & 0.58 \\
\hline 1-Octene-3-ol & 18.22 & 1.6 & 978 & 978 & 0.05 & 0.39 & 0.15 \\
\hline Sabinene & 18.22 & 0.88 & 978 & 975 & 0.41 & 0.87 & 0.97 \\
\hline Myrcene & 18.89 & 0.93 & 990 & 991 & 0.64 & 0.30 & 0.39 \\
\hline 3-Octanol & 19.15 & 1.52 & 995 & 993 & 0.05 & 0.17 & 0.09 \\
\hline a-Phellandrene & 19.49 & 0.84 & 1001 & 1005 & 0.04 & nd & nd \\
\hline (E)-Hex-3-enyl-acetate & 19.82 & 1.3 & 1007 & 1007 & 0.02 & nd & nd \\
\hline a-Terpinene & 20.42 & 0.97 & 1017 & 1018 & 0.1 & 0.02 & 0.02 \\
\hline p-Cymene & 20.95 & 1.14 & 1027 & 1026 & 0.11 & 0.13 & 0.12 \\
\hline Limonene & 21.22 & 1.14 & 1031 & 1029 & 1.21 & 0.86 & 1.04 \\
\hline 1,8-Cineole & 21.29 & 1.09 & 1033 & 1031 & 0.03 & 6.12 & 9.64 \\
\hline (Z)- $\beta$-ocimene & 22.22 & 1.01 & 1049 & 1040 & 0.06 & nd & nd \\
\hline Y-Terpinene & 22.75 & 1.05 & 1058 & 1062 & 0.17 & 0.05 & 0.05 \\
\hline Cis-Sabinene hydrate & 23.42 & 1.6 & 1070 & 1068 & 0.12 & 0.00 & 0.01 \\
\hline a-Terpinolene & 24.69 & 1.01 & 1092 & 1088 & 0.09 & 0.06 & 0.02 \\
\hline p-Cymenene & 24.75 & 1.3 & 1093 & 1089 & 0.01 & nd & nd \\
\hline 2-Nonanol & 25.02 & 1.56 & 1098 & 1098 & 0.03 & nd & nd \\
\hline Linalool & 25.29 & 1.68 & 1102 & 1097 & 1.33 & 0.37 & 0.74 \\
\hline Nonanal & 25.55 & 1.52 & 1107 & 1098 & 0.06 & 0.10 & 0.04 \\
\hline Allo-ocimene & 27.02 & 1.18 & 1133 & 1129 & 0.03 & nd & nd \\
\hline Unknown\#1 (MW152) & 27.55 & 1.3 & 1142 & $\mathrm{nn}$ & $\mathrm{Nd}$ & 0.96 & 1.26 \\
\hline Unknown\#2 (MW152) & 27.69 & 2.06 & 1144 & 1140 & $\mathrm{Nd}$ & 1.87 & 1.01 \\
\hline Menthofuran & 29.09 & 1.39 & 1169 & 1164 & 47.82 & 23.04 & 25.71 \\
\hline Isomenthone & 29.15 & 1.77 & 1170 & 1164 & 2.32 & 1.93 & 5.74 \\
\hline Unknown\#3 (MW152) & 29.69 & 1.6 & 1179 & $\mathrm{nn}$ & 0.0001 & 0.18 & 0.17 \\
\hline a-Terpineol & 30.69 & 1.85 & 1197 & 1189 & 3.71 & 1.11 & 2.08 \\
\hline decanal & 31.42 & 1.56 & 1210 & 1204 & 0.06 & 0.04 & 0.02 \\
\hline 4,7-dimethyl-benzofuran & 31.89 & 1.85 & 1218 & $\mathrm{nn}$ & 0.13 & 0.08 & 0.12 \\
\hline 2-a-Hydroxy-1,8-cineole & 32.42 & 2.4 & 1228 & 1228 & $\mathrm{Nd}$ & 4.88 & 3.81 \\
\hline Unknown\#4 (MW152) & 32.49 & 2.48 & 1229 & $\mathrm{nn}$ & 0.14 & nd & nd \\
\hline$\delta$-terpineol & 33.22 & 1.35 & 1243 & 1217 & 0.01 & 0.31 & 0.69 \\
\hline 3-a-Hydroxy-1,8-cineol & 33.35 & 2.53 & 1245 & 1246 & 0.0001 & 17.27 & 11.07 \\
\hline Pulegone & 33.49 & 1.85 & 1248 & 1237 & 17.52 & 2.47 & 5.36 \\
\hline 3- $\beta$-Hydroxy-1,8-cineol & 33.55 & 2.44 & 1249 & 1259 & $\mathrm{Nd}$ & 1.57 & 1.23 \\
\hline Unknown\#5 (MW170) & 33.89 & 2.15 & 1255 & 1232 & $\mathrm{Nd}$ & 0.60 & 0.23 \\
\hline Piperitone & 34.09 & 2.36 & 1259 & 1252 & 0.02 & nd & nd \\
\hline 9-OH cineole & 34.55 & 2.23 & 1267 & 1267 & $\mathrm{Nd}$ & 3.57 & 1.69 \\
\hline
\end{tabular}


Table 1 Quantitative descriptors of 2D peaks abundance is reported as 2D normalized volumes \% and referred to the TIC current signal; data is the mean of six biological replicates. As expected, the major leaf compound is menthofuran followed by high percentages of its precursor pulegone (Continued)

\begin{tabular}{|c|c|c|c|c|c|c|c|}
\hline Unknown\#8 (MW164) & 39.35 & 2.48 & 1358 & $\mathrm{nn}$ & $\mathrm{Nd}$ & 0.23 & 0.21 \\
\hline a-Cubebene & 39.42 & 1.26 & 1359 & 1351 & 0.03 & nd & nd \\
\hline a-Copaene & 40.55 & 1.26 & 1381 & 1376 & 0.02 & nd & nd \\
\hline$\beta$-Bourbonene & 41.35 & 1.35 & 1396 & 1384 & 0.01 & nd & nd \\
\hline$\beta$-Elemene & 41.62 & 1.39 & 1401 & 1391 & 0.05 & nd & nd \\
\hline Trans-Jasmone & 41.89 & 2.31 & 1407 & 1388 & 0.07 & nd & nd \\
\hline Unknown\#9 (MW166) & 41.95 & 3.03 & 1408 & $\mathrm{nn}$ & 0.0001 & 1.04 & 0.91 \\
\hline a-Gurjunene & 42.62 & 1.3 & 1422 & 1409 & 0.17 & nd & nd \\
\hline$\beta$-Cariophyllene & 43.15 & 1.52 & 1432 & 1419 & 0.67 & 0.24 & 0.22 \\
\hline Trans-aromadendrene & 43.89 & 1.39 & 1447 & 1439 & 0.07 & nd & nd \\
\hline a-Humulene & 44.82 & 1.47 & 1466 & 1454 & 0.05 & nd & nd \\
\hline Alloaromadendrene & 45.29 & 1.47 & 1476 & 1461 & 0.06 & nd & nd \\
\hline a-Amorphene & 45.89 & 1.39 & 1488 & 1485 & 0.08 & nd & nd \\
\hline Germacrene D & 46.22 & 1.6 & 1495 & 1485 & 0.09 & nd & nd \\
\hline a-Muurolene & 46.75 & 1.47 & 1506 & 1499 & 0.06 & nd & nd \\
\hline Bicyclogermacrene & 46.89 & 1.52 & 1509 & 1494 & 0.25 & nd & nd \\
\hline$\gamma$-Cadinene & 47.69 & 1.43 & 1526 & 1513 & 0.34 & 0.28 & 0.28 \\
\hline$\delta$-Cadinene & 48.09 & 1.43 & 1534 & 1524 & 0.25 & 0.13 & 0.17 \\
\hline Cadina-1,4-diene & 48.55 & 1.47 & 1544 & 1534 & 0.02 & nd & nd \\
\hline a-cadinene & 48.82 & 1.47 & 1550 & 1538 & 0.07 & 0.02 & 0.01 \\
\hline Germacrene D-4-ol & 50.35 & 2.1 & 1583 & 1576 & 0.03 & nd & nd \\
\hline$\beta$-Eudesmol & 51.29 & 2.1 & 1620 & 1649 & 0.02 & nd & nd \\
\hline a-cadinol & 53.55 & 1.98 & 1651 & 1653 & 0.02 & nd & nd \\
\hline
\end{tabular}

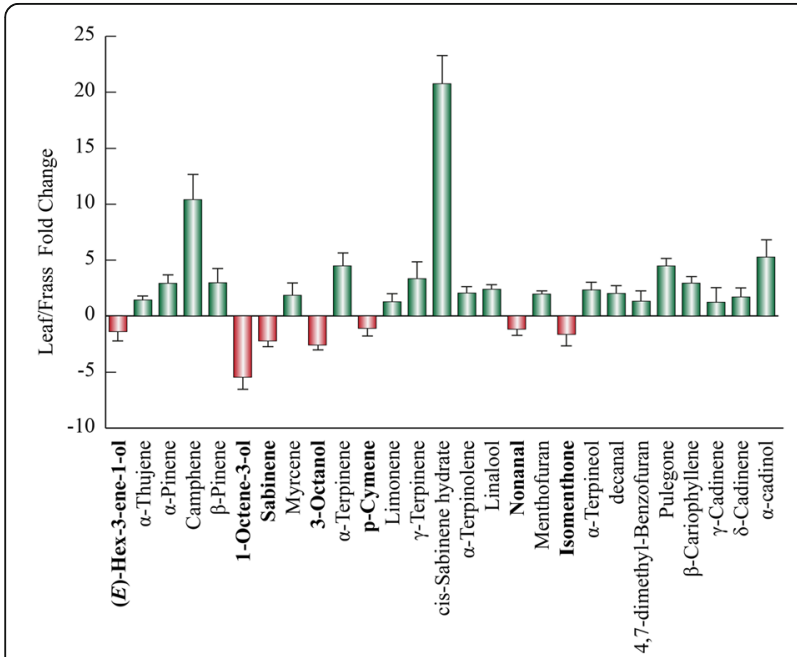

Fig. 1 Fold change values discriminating leaf and frass common components in the interaction betweem Mentha aquatica and Chrysolina herbacea. Orange bars and boldfaced compounds refer to frass extracts. Fold changes are expressed as Leaf value /Frass value. In order to express negative values, data are expressed as $-1 /(\mathrm{A} / \mathrm{B})$ when the $A / B$ value is $<1$, where $A$ and $B$ indicate, respectively, Leaf value and Frass value. Error bars represent standard deviations

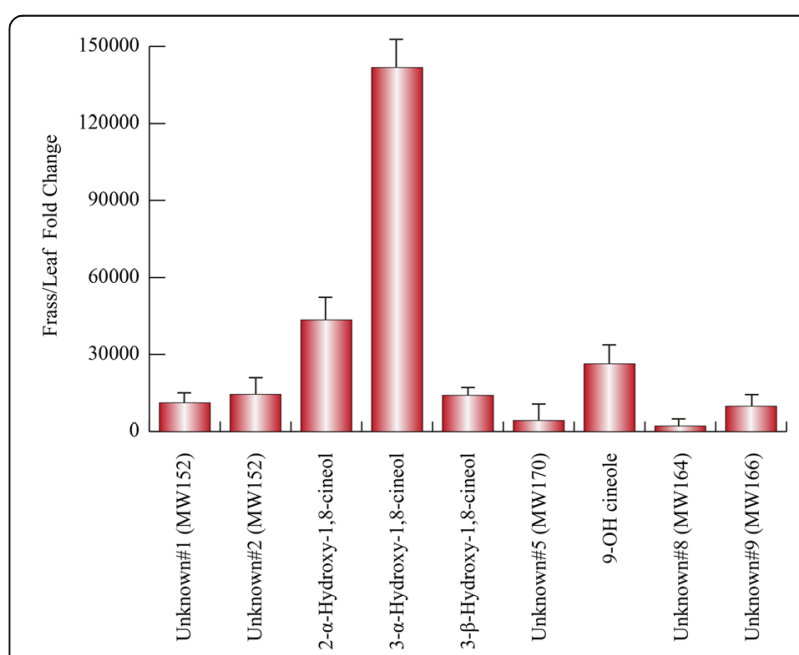

Fig. 2 Fold change values discriminating frass and leaf components in the interaction between Mentha aquatica and Chrysolina herbacea. Fold changes are expressed as Frass value /Leaf value. Error bars represent standard deviations 


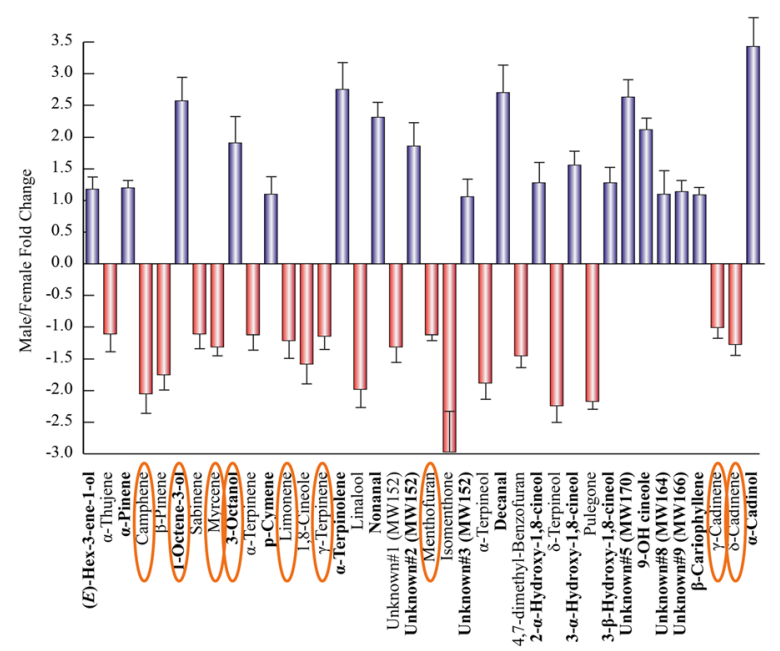

Fig. 3 Fold change values discriminating male and female frass components in the interaction betweem Mentha aquatica and Chrysolina herbacea. Blue bars and boldfaced compounds refer to male extracts. Fold changes are expressed as Male value /Female value. In order to express negative values, data are expressed as $-1 /(\mathrm{A} / \mathrm{B})$ when the $A / B$ value is $<1$, where $A$ and $B$ indicate, respectively, Male value and Female value. Error bars represent standard deviations.

Compounds that are also indicated in fig. 7 are circled in orange

Phylogenetic relationships between the 16S rRNA gene sequences of the cultivable $C$. herbacea gut bacterial communities and those of their closely related reference strains are shown in Fig. 5 a-d. The phylogenetic analysis of the Enterobacteriaceae tree (Fig. 5a) demonstrated high similarity between CHF-B4, CHFB16, CHF-B17, CHF-B26, CHF-37 and CHF-G5 16S rRNA gene sequences and those of Serratia marcescens subsp. sakuensis $\mathrm{KRED}^{\mathrm{T}}$ [42] and S. marcescens subsp. marcescens DSM 30121 ${ }^{\mathrm{T}}$ [43]. CHM-N28 isolate clustered with the type strain Serratia liquefaciens CIP $103238^{\mathrm{T}}$ [44] (Fig. 5a), while the 16S rRNA gene sequence of the isolate CHF-G14 sequence closely allied to that of Pantoea vagans LMG 24199 ${ }^{\mathrm{T}}$ [45] (Fig. 5a).

The phylogenetic analysis of the Pseudomonadaceae tree (Fig. 5b) showed that isolates CHF-PG1 and CHFPG3 branched in a cluster including the reference strains Pseudomonas psychrotolerans DSM $15758^{\mathrm{T}}$ [46] and Pseudomonas oleovorans subsp. oleovorans ATCC $8062^{\mathrm{T}}$ [47]. Furthermore, it collocated the isolates CHM-N25 and CHM-N31 in the Pseudomonas salomonii CFBP $2022^{\mathrm{T}}$ cluster [48].

The phylogenetic analysis of the Sphingomonadaceae tree (Fig. 5c) highlighted that the isolate CHF-PG4 branched in a new taxonomic cluster. Indeed, its $16 \mathrm{~S}$ rRNA gene sequence showed a low similarity $(97.62 \%)$ with that of the reference strain Sphingomonas pseudosanguinis G1-2 ${ }^{\mathrm{T}}$ [49] (Table 2).
Lastly, phylogenetic data collocated CHM-L11 in the Bacillus cereus group including eight closely related species: B. cereus [50], B. anthracis [51], B. thuringiensis [52], B. toyonensis [53], B. mycoides [54], B. pseudomycoides [55], B. weihenstephanensis [56] and B. cytotoxicus [57] (Fig. 5d). CHM-L21 and CHM-L22 clustered together with the reference strain Bacillus firmus NCIMB $9366^{\mathrm{T}}$ [58] (Fig. 5d).

\section{Limited culture-independent molecular analysis of gut-associated bacterial communities}

The sex-specific distribution of cultivable gut bacteria led us to explore the bacterial community diversity by limited culture-independent molecular analysis targeting 16S rRNA gene sequences from Firmicutes, $\alpha$ - and $\gamma$-Proteobacteria. The analysis was carried out by firstly amplifying 16S rRNA gene sequences from male and female gut communities using bacterial broad-range primer pairs in standard PCR, and then analyzing the relative amounts of amplifiable Firmicutes, $\alpha$ - and $\gamma$ Proteobacteria 16S rRNA gene sequences by semiquantitative real-time PCR using phylum/subphylumspecific primer pairs (Fig. 6 and Additional file 2: File S1). In agreement with culture-dependent analysis, the results of real-time PCR experiments confirmed the presence of $\gamma$-Proteobacteria 16S rRNA gene sequences in all samples with quantitative values higher in samples from male than from female individuals (Fig. 6 and Additional file 2: File S1). Moreover, real time PCR amplification with primers specific for $\alpha$-Proteobacteria, which could not be isolated from males, provided quantitative values lower in samples from males than from females individuals. However, in contrast with the data of culturedependent analysis showing the absence of Firmicutes in the cultivated gut community from females, real time PCR amplification with Firmicutes-specific primers produced amplifiable signals in the DNA samples from both males and females with almost similar quantitative values in both sexes. This discrepancy can be traced to possible sex-specific differences in the structures of Firmicutes from males and females, and to unsuitable cultivation conditions for isolation of several members of Firmicutes (including anaerobic strains) whose presence could be detected by realtime PCR.

\section{Cross-inhibition tests with isolated gut bacteria from C. herbacea female and male individuals}

The qualitative difference in the cultivable gut bacterial community found in the two sexes may reflect the sexual dimorphism (females are typically larger than males) of $C$. herbacea due to anatomic differences in the gut. However, to better understand this aspect we tested a possible growth incompatibility among the 


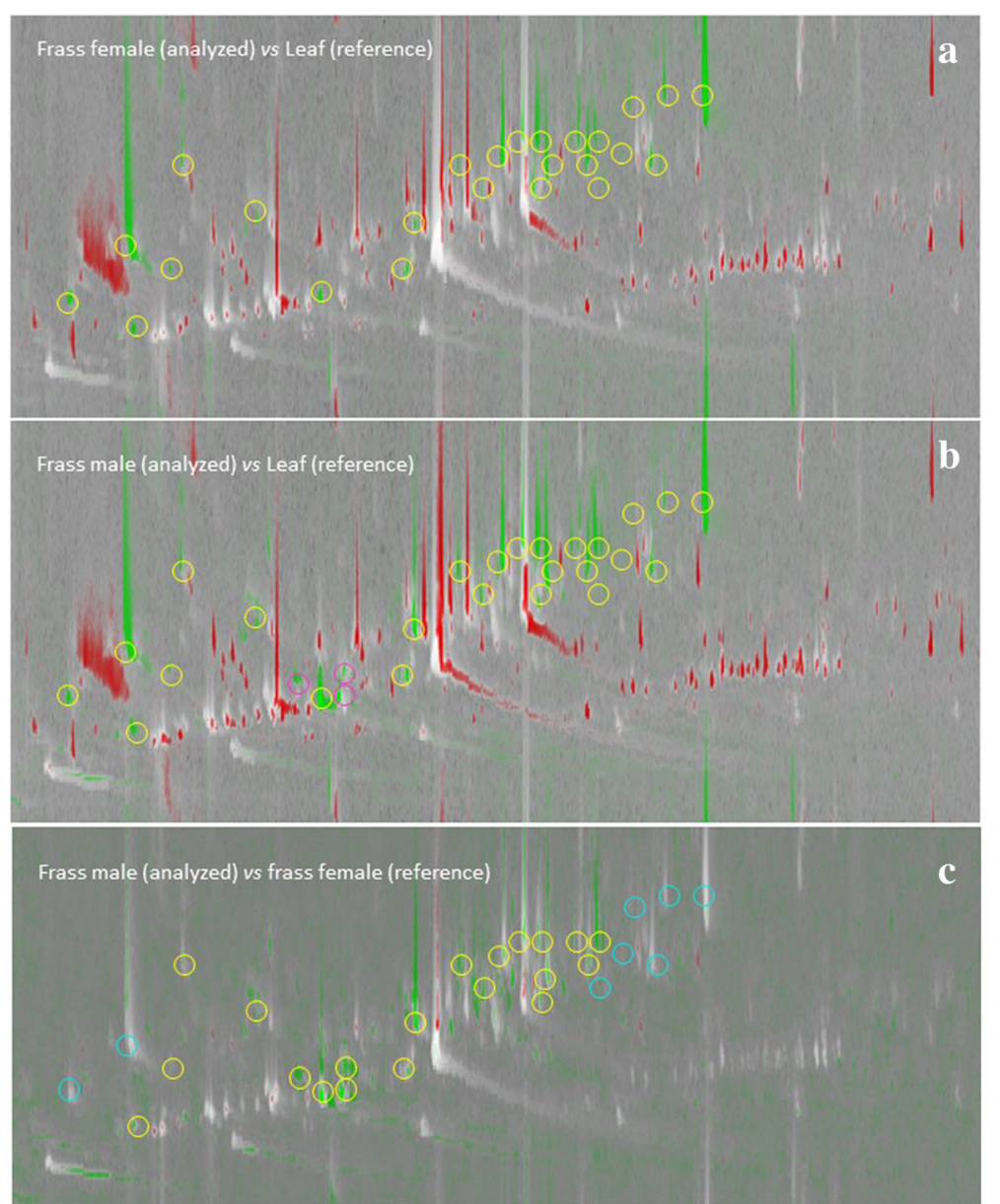

Fig. 4 GCXGC two-dimensional analysis pseudocolor comparison of Mentha aquatica leaf volatiles and Chrysolina herbacea frass volatiles. a, pseudocolor comparison of M. aquatica leaf volatiles (reference image) compared to the frass volatiles distribution from (c). herbacea female population feeding on M. aquatica leaves. b, pseudocolor comparison of M. aquatica leaf volatiles (reference image) compared to the frass volatiles distribution from C. herbacea male population feeding on $M$. aquatica leaves. c, comparative image between females C. herbacea frass volatiles (reference image) vs. male C. herbacea frass volatiles. See text for explanation

isolates by performing a series of cross-inhibition tests as detailed in Methods (Table 3 and Additional file 1: Figure S2). As shown in Table 3, five gut isolates from $C$. herbacea females (CHF-B4, CHF-B16, CHF-B17, CHF-B26 and CHF-B37), phylogenetically related to the $\gamma$-Proteobacterium Serratia marcescens subsp. sakuensis, determined zones of growth inhibition on three isolates from males (CHM-L11, CHM-L21, CHM-L22) belonging to the genus Bacillus of the Firmicutes group with diameters ranging from 0.52 to $3.52 \mathrm{~cm}$. In addition, these five bacteria possessed an antibacterial activity against three others Gram-positive tester microorganisms such as Staphylococcus aureus [59], Micrococcus luteus [60] and the actinomycete Streptomyces ambofaciens [61]. The assayed microorganisms were able to produce zones of growth inhibition on tester strains with diameters between 0.90 and $2.93 \mathrm{~cm}$ (Table 3). In contrast, they did not show any antibacterial effect on either $\gamma$-Proteobacterial isolates from males (CHM-N25, CHM-N28 and CHM-N31) or two $\gamma$-Proteobacterial tester microorganisms, E. coli [62] and S. enterica [63]. Conversely, no gut strain isolated from males showed detectable antibacterial activity against isolates from females and tester microorganisms. Notably, the rifamycin B producer A. mediterranei 5699 showed diameters of growth inhibition against the three Gram-positive isolates from males (CHM-L11, CHM-L21, CHM-L22) ranging from 2.2 and $2.8 \mathrm{~cm}$. These inhibition values were similar to those found with the five gut isolates from females (CHFB4, CHF-B16, CHF-B17, CHF-B26 and CHF-B37) supporting their strong antibacterial activity.

\section{Ability of gut bacteria to metabolize $M$. aquatica essential oil}

In order to clarify the possible role of the gut bacterial communities from $C$. herbacea female and male 
Table 2 Taxonomic identification of the gut bacterial isolates from females (CHF) and males (CHM) of C. herbacea on the basis of the 165 rRNA gene sequencing

\begin{tabular}{|c|c|c|c|c|}
\hline Strain designation & Closest relative strain according to Ez-Taxon & Phylum & $\begin{array}{l}\text { Accession number of the } \\
\text { closest relative strain }\end{array}$ & 16S rRNA similarity (\%) \\
\hline${\mathrm{CHF}-\mathrm{B} 4^{\mathrm{a}}}$ & Serratia marcescens subsp. sakuensis KRED ${ }^{\top}$ & Y-Proteobacteria & AB061685 & 99.12 \\
\hline $\mathrm{CHF}-\mathrm{B} 16^{\mathrm{a}}$ & Serratia marcescens subsp. marcescens DSM $30121^{\top}$ & Y-Proteobacteria & AJ233431 & 99.65 \\
\hline $\mathrm{CHF}-\mathrm{B} 17^{\mathrm{a}}$ & Serratia marcescens subsp. sakuensis KRED ${ }^{\top}$ & ү-Proteobacteria & AB061685 & 99.80 \\
\hline CHF-B26 ${ }^{\mathrm{a}}$ & Serratia marcescens subsp. sakuensis KRED ${ }^{\top}$ & Y-Proteobacteria & AB061685 & 99.89 \\
\hline $\mathrm{CHF}-\mathrm{B} 37^{\mathrm{a}}$ & Serratia marcescens subsp. sakuensis KRED ${ }^{\top}$ & -Proteobacteria & AB061685 & 99.63 \\
\hline $\mathrm{CHF}-\mathrm{G} 5^{\mathrm{a}}$ & Serratia marcescens subsp. sakuensis KRED ${ }^{\top}$ & Y-Proteobacteria & AB061685 & 99.51 \\
\hline CHF-G14 & Pantoea vagans $L M G 24199^{\top}$ & ү-Proteobacteria & EF688012 & 99.93 \\
\hline $\mathrm{CHF}-\mathrm{PG} 1^{\mathrm{a}}$ & Pseudomonas psychrotolerans $\mathrm{C} 36^{\top}$ & Y-Proteobacteria & AJ575816 & 99.63 \\
\hline CHF-PG3 ${ }^{\mathrm{a}}$ & Pseudomonas psychrotolerans $\mathrm{C} 6^{\mathrm{T}}$ & ү-Proteobacteria & AJ575816 & 99.79 \\
\hline CHF-PG4 ${ }^{a}$ & Sphingomonas pseudosanguinis $\mathrm{G} 1-2^{\top}$ & a-Proteobacteria & AM412238 & 97.62 \\
\hline CHM-L $11^{\mathrm{b}}$ & Bacillus anthracis ATCC $14758^{\top}$ & Firmicutes & AB190217 & 99.85 \\
\hline $\mathrm{CHM}-\mathrm{L} 21^{\mathrm{b}}$ & Bacillus firmus NCIMB $9366^{\top}$ & Firmicutes & X60616 & 99.83 \\
\hline $\mathrm{CHM}-\mathrm{L} 22^{\mathrm{b}}$ & Bacillus firmus NCIMB $9366^{\top}$ & Firmicutes & X60616 & 100.00 \\
\hline $\mathrm{CHM}-\mathrm{N} 25^{\mathrm{b}}$ & Pseudomonas salomonii CFBP $2022^{\top}$ & Y-Proteobacteria & AY091258 & 99.49 \\
\hline $\mathrm{CHM}-\mathrm{N} 28^{\mathrm{b}}$ & Serratia liquefaciens ATCC $27592^{\top}$ & ү-Proteobacteria & CP006252 & 99.72 \\
\hline $\mathrm{CHM}-\mathrm{N} 31^{\mathrm{b}}$ & Pseudomonas extremorientalis KMM $3447^{\top}$ & Y-Proteobacteria & AF405328 & 99.20 \\
\hline
\end{tabular}

${ }^{a}$ isolated from females; ${ }^{b}$ isolated from males

individuals in the adaptation of C. herbacea to M. aquatica volatiles, we assayed the ability of these isolated gut bacteria to grow either individually or in community utilizing essential oil as the sole carbon (and energy) source. All 16 bacterial isolates were able to grow well either on solid or in liquid SRM-oil media. In particular, in liquid SRM-oil media, all tested bacteria reached a mean value of $1.0 \mathrm{OD}_{600} / \mathrm{mL}$ after an incubation time of $24 \mathrm{~h}$ at $30{ }^{\circ} \mathrm{C}$ (data not shown). The ability of the gut bacteria to grow individually using the essential oil as sole carbon source prompted us to investigate the possible modification of the essential oil components carried out by the two bacterial communities using an in vitro approach. Bacteria from males or females were co-cultivated in the presence of $M$. aquatica essential oil as detailed in the Methods section, and then essential oil components were extracted from the exhausted growth medium by Stir Bar Sorptive Extraction (SBSE) technique and subjected to quantitative analysis by Gas chromatography-mass spectrometry (GCMS) (Fig. 7).

GC-MS analysis highlighted the ability of gut bacteria to modify the terpene composition of the M. aquatica essential oil as compared to controls without bacteria (Fig. 7). 3-nonanol (\#22), $\beta$-bourbonene (\#26), isopulegol (\#29), $\alpha$-amorphene (\#40) and longipinanol (\#72) were exclusively detected in the females gut bacterial community supernatant (Fig. 7). In contrast, 3-nonanol (\#22) and isopulegol (\#29) were the new compounds revealed in the male community supernatant (Fig. 7). These compounds were totally absent in the control essential oil (Fig. 7). Furthermore, the two communities were able to alter the main essential oil components such as menthofuran (\#24), menthone (\#23), 1,8-cineole (\#10), limonene (\#9) and pulegone (\#36). As shown in Fig. 7, menthofuran was degraded both by females and males gut bacterial communities. In contrast, with reference to the compounds menthone, 1,8-cineole and pulegone, both gut communities were able to enhance their concentration with respect to the control essential oil. Whilst D-limonene was degraded by male community, its level was enhanced by metabolic activity of the female community. These results were indicative of a potential ability of the gut bacteria to modify the terpene profile of $M$. aquatica essential oil thereby modulating the plant-insect interaction.

\section{Discussion}

The interaction between bacteria and insects is becoming a major topic of discussion, particularly when bacteria contribute to insect fitness through their involvement in food digestion. This interaction provides insect with better nutrition, detoxification, pheromone production, regulation of $\mathrm{pH}$, synthesis of vitamins and sterols, temperature tolerance, resistance against pathogens and parasitoids. Gut bacteria can even modify the use of host plants by phytophagous insects [22, 64-66], thereby affecting insects development, defense against natural enemies, immunity, reproduction, and speciation [22, 67-73]. 


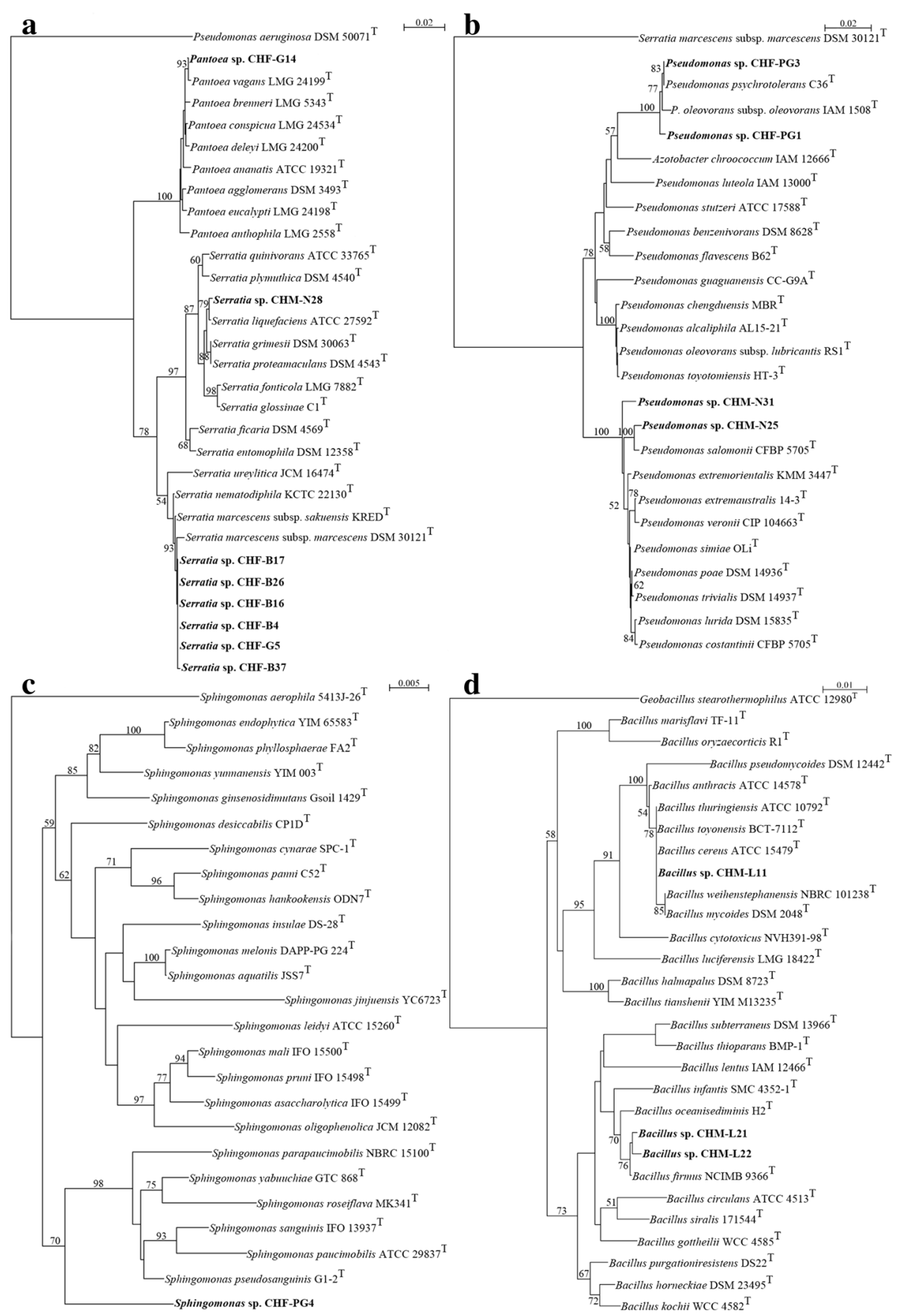

Fig. 5 NJ phylogenetic tree based on 165 rRNA gene sequencing of cultivable gut bacteria from females (CHF) and males (CHM) of C. herbacea. The phylogenetic relationships of the Serratia spp. CHF-B4, CHF-B16, CHF-B17, CHF-B26, CHF-B37, CHF-G5, CHM-N28 and Pantoea sp. CHF-G14 (a), the Pseudomonas spp. CHF-PG1, CHF-PG3, CHM-N25 and CHM-N31 (b), the Sphingomonas sp. CHF-PG4 (c), the Bacillus spp. CHM-L11, CHM-L21 and CHM-L22 (d) are shown with respect to reference strains. Bootstrap values (expressed as percentages of 1000 replicates) $\geq 50$ are depicted at the branch points. Pseudomonas aeruginosa DSM 50071 ${ }^{\top}$, Serratia marcescens subsp. marcescens DSM $30121^{\top}$, Sphingomonas aerophila $5413 \mathrm{~J}-26^{\top}$ and Geobacillus stearothermophilus ATCC $12980^{\top}$ were used as outgroups in A, B, C and D respectively. Bars, substitutions per nucleotide position

In the current study, the role of the cultivable gut bacteria of $C$. herbacea male and female individuals in the high specific relationship between this herbivore and $M$. aquatica was investigated. By using a combination of chemical pattern and culture-dependent approach, we found marked qualitative differences in the two sexes. It is interesting to observe, as preliminary information about differential metabolism, that female frass analytes 


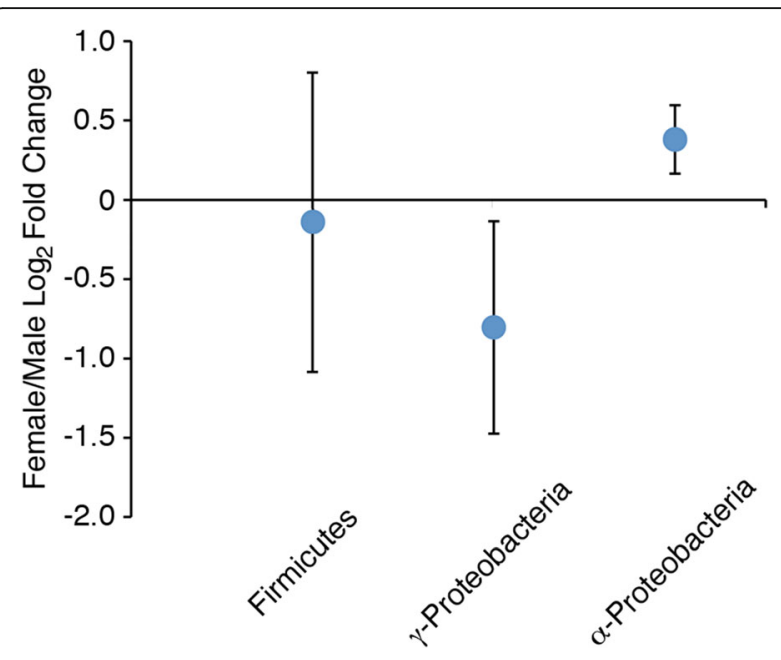

Fig. 6 Limited culture-independent analysis of $C$. herbacea male and female gut bacteria. Relative abundance of Firmicutes, $a-$ and Y-Proteobacteria 16S rRNA gene sequences in C. herbacea male and female guts was determined by real-time PCR using phylum/ subphylum specific primer pairs. Results are expressed as female/male $\log _{2}$ fold changes (circles) \pm standard deviations (error bars)

$(30.05 \mu \mathrm{g} / \mathrm{g} \pm 2.63)$ are present in a higher concentration with respect to male frass analytes $(17.41 \mu \mathrm{g} / \mathrm{g} \pm 2.05)$. The algorithm enabling the highly reliable and specific fingerprinting approach used in this work has been demonstrated to be successful for complex patterns investigations: including breast cancer metabolomics [74], biooils characterization [75] and mice urine metabolite profiling [76], whereas the peak-region features approach consists of a sequence of operations as previously detailed [77-80].

The sex-specific chemical pattern of the frass paralleled with sex-specific distribution of cultivable gut bacteria. The bacterial isolation procedure revealed the selective presence of $\alpha$ - and $\gamma$-Proteobacteria in the intestinal tract of females; in contrast, the gut of males contained both $\gamma$-Proteobacteria and Firmicutes (Table 2). This result was only partially consistent with that of limited culture-independent molecular analysis targeting 16S rRNA gene sequences from Firmicutes, $\alpha$ - and $\gamma$-Proteobacteria (Fig. 6 and Additional file 2: File S1). The analysis confirmed the presence of $\gamma$-Proteobacteria in both male and female intestines, and demonstrated lower abundance of $\alpha$-Proteobacteria in the cultivable gut community from males. However, it revealed a large presence of Firmicutes in male intestine emphasizing the wellknown limits of culture-based methods.

Most of the gut bacterial isolates from the two sexes are taxonomically related to species previously found as insect gut bacteria [81]. The isolates CHF-B4, CHF-B16, CHF-B17, CHF-B26, CHF-B37 and CHF-G5 from females are phylogenetically close to $S$. marcescens (Fig. 5a), a $\gamma$-Proteobacterium associated to numerous species and genera of the order Orthoptera (crickets and grasshoppers), Isoptera (termites), Coleoptera (beetles and weevils), Lepidoptera (moths), Hymenoptera (bees and wasps), and Diptera (flies) [81]. CHM-N28 isolate from males is phylogenetically identical to S. liquefaciens (Fig. 5a), found in association with S. marcescens in sugarbeet root-maggot (Tetanops myopaeformis) developmental stages, suggesting an insect-microbe symbiosis, as well as a nutritional interdependence [82]. On the other hand, S. marcescens and S. liquefaciens are also considered potential insect pathogens for more than 70 species [83]. As demonstrated by Stephens [84], the hemolymph of insects, which is normally bactericidal for nonpathogens, cannot prevent multiplication of potential pathogens. Antibacterial substances in ingested leaves might interfere with bacterial multiplication, but strains of this genus were found resistant to these [85]. Moreover, lecithinase, proteinase, and chitinase play a crucial role in the virulence of Serratia for insects, and purified Serratia proteinase or chitinase is very toxic when injected into the hemocoel $[86,87]$.

CHF-G14 isolate is phylogenetically related to the Gram-negative $\gamma$-Proteobacterium P. vagans (Fig. 5a). $P$. vagans strain C9-1 was found recently associated with the fungus-growing ants [88]. CHF-PG1 and CHF-PG3 on the basis of the $16 \mathrm{~S}$ rRNA gene sequencing appeared to be close to Pseudomonas psychrotolerans and P. oleovorans subsp. oleovorans (Fig. 5B), while, the isolates CHM-N25 and CHM-N31 were strictly related to $P$. salomonii (Fig. 5B). To our knowledge, these species of the genus Pseudomonas were never found as insect gut colonizers. Molecular data showed that the isolate CHF-PG4 did not belong to a previously characterized species of the genus Sphingomonas and occupied a distinct taxonomical position (Fig. 5C). Sphingomonas spp. were isolated from guts of Manduca sexta [89], Anopheles stephensi [90], Helicoverpa armigera [91] and Homalodisca vitripennis [92]. Lastly, CHM-L11 was taxonomically near to B. thuringiensis; whilst CHM-L21 and CHM-L22 were biochemically and phylogenetically identified as B. firmus strains (Fig. 5d). Strains of B. thuringiensis have been isolated worldwide from many habitats including soil, insects, stored-product dust, and deciduous and coniferous leaves [93]. Notably, B. thuringiensis proliferates in the guts of various insects before killing its hosts [94]. B. firmus was isolated, by using cultivable techniques, from guts of the lepidopteran pest Helicoverpa armigera [91].

In order to better clarify why the bacterial communities were qualitatively different, we tested their possible growth incompatibility. We demonstrated that the five gut isolates from females (CHF-B4, CHF-B16, CHF-B17, CHF-B26, CHF-B37) that were taxonomically and 


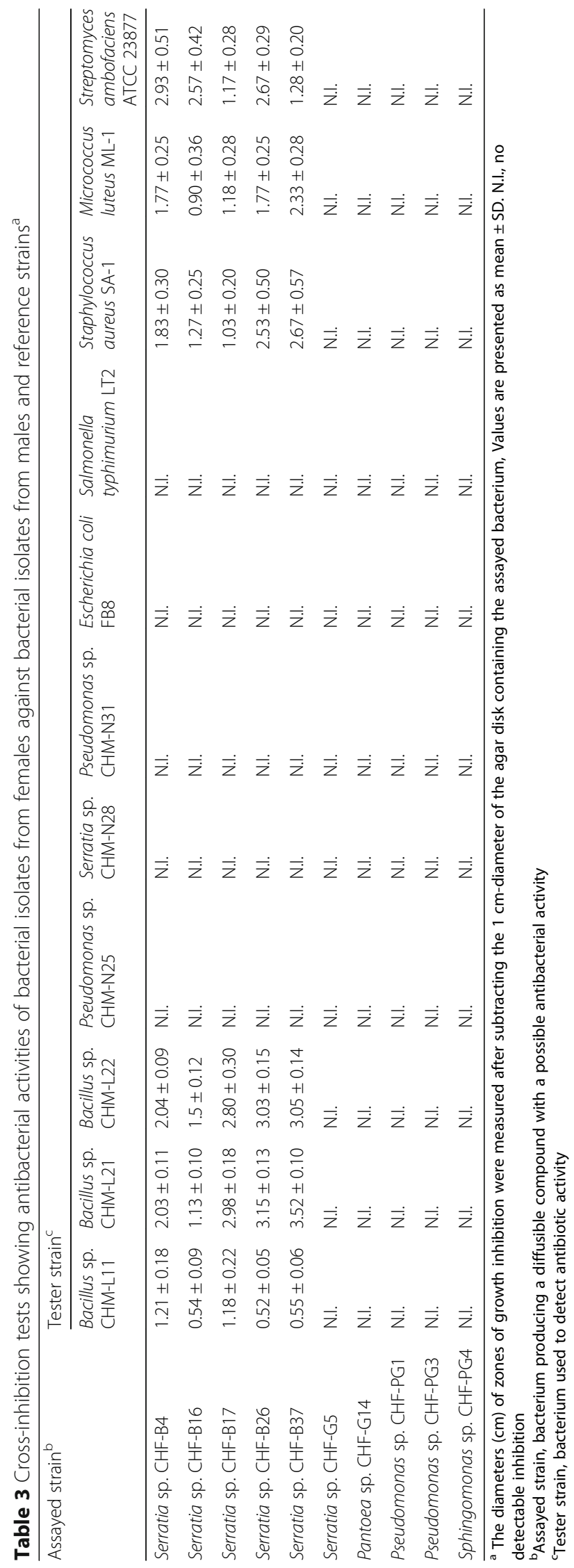




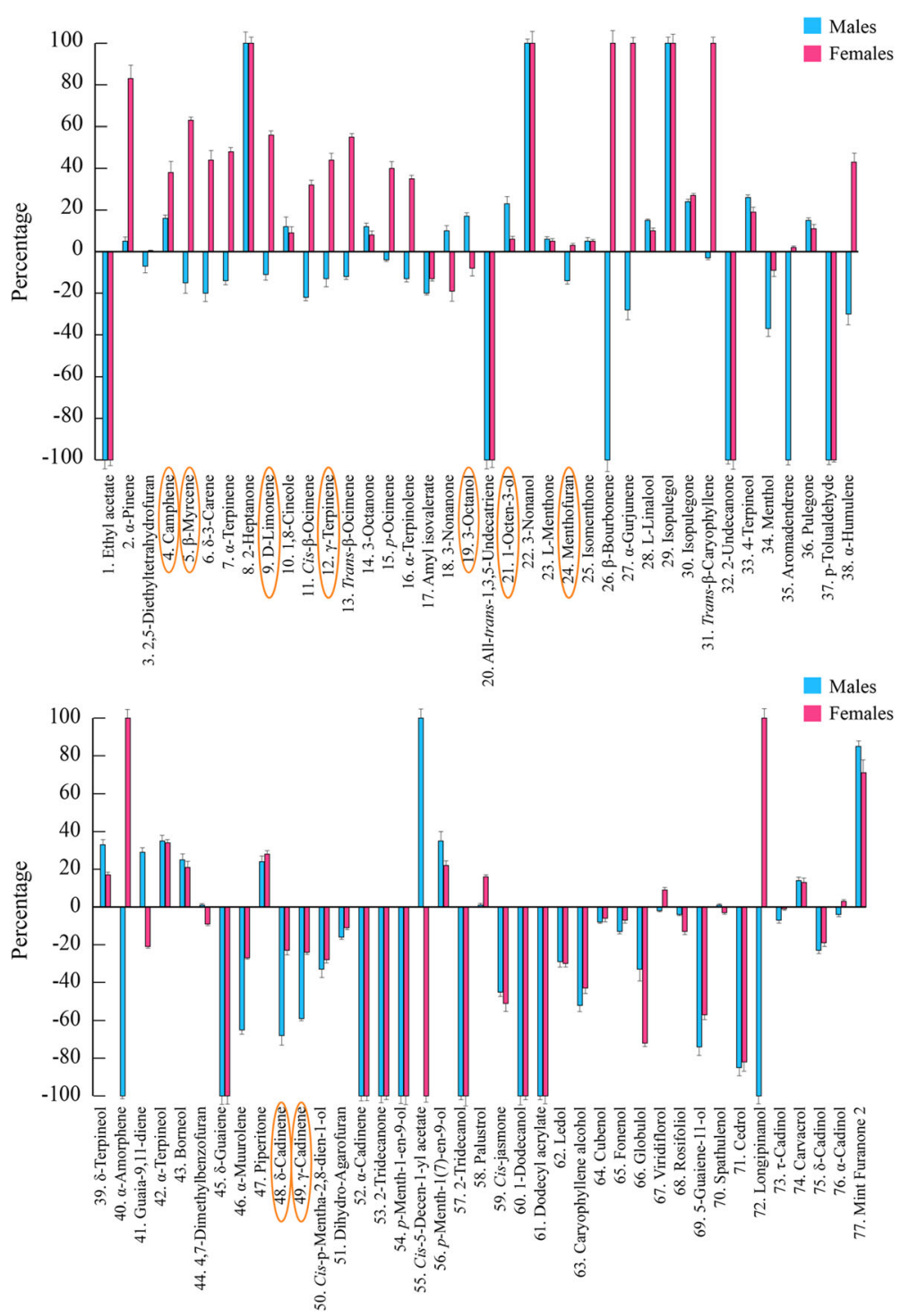

Fig. 7 Biotransformation of M. aquatica essential oil by C. herbacea sex-specific gut microbial communities. M. aquatica essential oil was incubated with gut bacteria co-cultures from C. herbacea male and female individuals, and male (blue)- and female (red)-specific terpene profiles were determined by SBSE and GC-MS. Values are expressed as percentage increase/decrease with respect to the control without bacteria. Detected compounds: 1, ethyl acetate; 2, a-pinene; 3, 2,5-diethyltetrahydrofuran; 4, camphene; 5, $\beta$-myrcene; 6, 8 -3-carene; 7, a-terpinene; 8, 2-heptanone; 9, (-)-limonene; 10, 1,8-cineole; 11, cis- $\beta$-ocimene; 12, $\gamma$-terpinene; 13, trans- $\beta$-ocimene; 14, 3-octanone; 15, p-ocimene; 16, a-terpinolene; 17, amyl isovalerate; 18, 3-nonanone; 19, 3-octanol; 20, all-trans-1,3,5-undecatriene; 21, 1-octen-3-ol; 22, 3-nonanol; 23, (-)-menthone; 24, (+)-menthofuran; 25, isomenthone; 26, $\beta$-bourbonene; 27, a-gurjunene; 28, L-linalool, 29, isopulegol; 30, isopulegone; 31, trans- $\beta$-caryophyllene; 32, 2-undecanone; 33, 4-terpineol; 34, menthol; 35, aromadendrene; 36, (+)-pulegone; 37, p-tolualdehyde; 38, a-humulene; 39, $\delta$-terpineol; 40, a-amorphene; 41, guaia-9,11-diene; 42, a-terpineol; 43, borneol; 44, 4,7-dimethylbenzofuran; 45, $\delta$-guaiene; 46, a-muurolene; 47, piperitone; 48, $\delta$-cadinene; 49, Y-cadinene; 50, cis-p-mentha-2,8-dien-1-ol; 51, dihydro-agarofuran; 52, a-cadinene; 53, 2-tridecanone; 54, p-menth-1-en-9-ol; 55, cis-5-decen-1-yl acetate; 56, p-menth-1(7)-en-9-ol; 57, 2-tridecanol; 58, palustrol; 59, cis-jasmone; 60, 1-dodecanol; 61, dodecyl acrylate; 62, ledol; 63, caryophyllene alcohol; 64, cubenol; 65, fonenol; 66, globulol; 67, viridiflorol; 68, rosifoliol; 69, 5-guaiene-11-ol; 70, spathulenol; 71, cedrol; 72, longipinanol; 73, т-cadinol; 74, carvacrol; 75, 8 -cadinol; 76, a-cadinol; 77, mint furanone 2. Error bars represent standard deviations. Compounds that are also indicated in Fig. 3 are circled in orange

biochemically identified as non-pigmented $S$. marcescens strains had an antibacterial activity against isolates from males belonging to the genus Bacillus (CHM-L11, CHM-L21, CHM-L22) (Additional file 1: Figure S2). A similar antibacterial activity was found against the other
Gram-positive bacteria used as tester microorganisms including $S$. aureus, $M$. luteus and $S$. ambofaciens (Table 3). In all other cases, no detectable growth inhibition was found. These results are consistent with the finding that no strains belonging to $S$. marcescens were 
isolated from male guts, where many Gram-positive bacteria were found.

We provide evidence that the gut bacteria of $C$. herbacea are able to metabolize M. aquatica essential oil components. Interestingly, a correlation was found between the pattern of frass volatiles distribution in male and female individuals (Fig. 3) and that of bio-transformed oil compounds by the cultivable microbial communities (Fig. 7). In particular, 9 out of 32 (about 28\%) identified frass volatiles (i.e., camphene, 1-octene-3-ol, myrcene, 3octanol, limonene, $\gamma$-terpinene, menthofuran, $\gamma$-cadinene and $\delta$-cadinene; circled in orange in Figs. 3 and 7) exhibited differential increase/decrease percentage in biotransformation experiments in agreement with their relative abundance in frass. This result may provide an indirect measure of how the cultivated microbial community is representative of the actual in situ community.

The two bacterial communities from both female and male individuals were able to utilize and biotransform in vitro many terpenoids into an array of new compounds, which were absent in control samples (Fig. 7). In particular, five (3-nonanol, $\beta$-bourbonene, isopulegol, $\alpha$ amorphene, longipinanol) and two (3-nonanol, $\beta$ bourbonene) new compounds were detected in the exhausted media from females and males bacterial communities, respectively. 3-nonanol (compound \#22 in Fig. 7) has been found in the mandibular gland secretions of the ant Crematogaster sjostedti, which could facilitate species identification and lead to species-specific alarm and defense responses that influenced their competitive interactions [95]. $\beta$-bourbonene (\#26 in Fig. 7) was found to be a plant-derived pheromone compound [96] released by the insect herbivore Euceraphis punctipennis [97]. Isopulegol (\#29 in Fig. 7) is a pheromone [96] tracked in the pygidial gland secretions of the ant Azteca chartifex [98]. $\alpha$-amorphene (\#40 in Fig. 7) is present in the larval osmeterial secretions produced by disturbed Pachliopta aristolochiae individuals in order to stave off numerous predators [99]. Numerous published studies have demonstrated the role of bacteria in plant terpene and terpenoid metabolism [100-105]. Although we only focused on cultivable gut bacteria, we hypothesize that these new volatile organic compounds, possibly derived from plant terpenoids as a consequence of gut bacterial metabolisms, could be used as recruitment signals (produced by both bacterial communities) or sex pheromones (produced by the bacterial community from female individuals) by insects. In this regard it is noteworthy that the cultivated bacterial community from female individuals produced a more varied blend than that from males including new compounds (i.e., that were absent in control samples) with potential sex pheromone activity ( $\beta$-bourbonene [\#26 in Fig. 7], $\alpha$ amorphene [\#40 in Fig. 7]).
In addition, we found that the two bacterial communities altered the profile of the two main essential oil components menthofuran (\#24) and pulegone (\#36). Both bacterial communities degraded menthofuran and enhanced the concentration of pulegone with respect to the control essential oil (Fig. 7). Pulegone is a terpene produced by intact $M$. aquatica plants to attract individuals of $C$. herbacea; in contrast, menthofuran is produced by infested plants and has a potent repellent activity on C. herbacea [10].

\section{Conclusions}

This study focuses on the multitrophic association among $M$. aquatica, its specific herbivore C. herbacea, and the insect gut microbial community. The results support the evidence that, by modulating the plantderived terpenoid profile, gut bacteria of $C$. herbacea play a crucial role in co-adaptation between plants and insects enabling a highly specific relationship between $M$. aquatica and $C$. herbacea. Furthermore, these microbial volatile organic compounds (MVOCs) could be exploited as an eco-friendly, cost-effective, and sustainable strategy for agricultural practices $[16,35]$.

\section{Methods}

\section{Plant and animal material}

Stolons of Mentha aquatica L. were collected from wild populations growing in Cambiano (Turin province, Italy, alt $240 \mathrm{~m}$ a.s.l.). Plants were grown as reported earlier [10]. Adults of Chrysolina herbacea (Duftschmidt 1825) (Coleoptera, Chrysomelidae, Chrysomelinae) were collected by hand picking from infested M. aquatica fields. After collection, beetles were reared at $22{ }^{\circ} \mathrm{C}$ in ventilated glass chambers and fed with $M$. aquatica cuttings. The beetles were starved for $24 \mathrm{~h}$ prior the experiments.

\section{Essential oil distillation}

One $\mathrm{Kg}$ of fresh leaves collected from $M$. aquatica cuttings were hydrodistilled with a modified Clevenger apparatus [106] and the essential oil was collected, dried over anhydrous ammonium sulphate and stored at $5{ }^{\circ} \mathrm{C}$ for further studies.

\section{Collection of plant volatiles from M. aquatica leaves and C. herbacea frass}

Fresh leaves (about $50 \mathrm{mg}$ ) from living plants of $M$. aquatica were carefully picked-off immediately before the analysis and gently placed in hermetically sealed $2.0 \mathrm{~mL}$ vials for HS-SPME sampling. Frass fluid collected from Chrysolina herbacea populations reared on $M$. aquatica leaves was immediately transferred to exactly weighted $2.0 \mathrm{~mL}$ headspace vials and left to ambient conditions for a fixed time. After $30 \mathrm{~min}$, vials were exactly weighted (to estimate the loss of weight due to water/sample 
evaporation) and hermetically sealed before HS-SPME sampling. Divinylbenzene/Carboxen/Polydimethylsiloxane (DVB/CAR/PDMS) df 50/30 $\mu \mathrm{m}, 2 \mathrm{~cm}$ length SPME fiber device was manually inserted into the sealed vial and the fiber exposed to the matrix headspace for volatile sampling. The Internal Standard (ISTD) loading procedure onto the SPME device was performed as previously described [77] using $\alpha$-thujone. Then, the fiber was exposed to the headspace at room temperature for $20 \mathrm{~min}$. After the ISTD loading, the fiber was exposed to the frass headspace again for $20 \mathrm{~min}$ at room temperature.

Frass analyte concentration was calculated based on external calibration curves using mono and sesquiterpenes.

\section{GC $\times$ GC-MS analysis of volatiles}

GC $\times$ GC analyses were carried out on an Agilent 6890 GC unit coupled with an Agilent 5975 MS detector operating in EI mode at $70 \mathrm{eV}$ (Agilent, Little Falls, DE, USA). Transfer line was set at $270{ }^{\circ} \mathrm{C}$, and ion source at $230{ }^{\circ} \mathrm{C}$. A Standard Tune option was used with a scan range of $35-250 \mathrm{~m} / \mathrm{z}$ at $12,500 \mathrm{amu} / \mathrm{s}$ and a resulting acquisition frequency of $30 \mathrm{~Hz}$. The system was provided with a two-stage thermal modulator (KT 2004 loop modulator from Zoex Corporation, Houston, TX, USA) cooled with liquid nitrogen and with the hot jet pulse time set at $250 \mathrm{~ms}$ with modulation time of $4 \mathrm{~s}$. The hot-jet temperature programme was from $160{ }^{\circ} \mathrm{C}$ to $250{ }^{\circ} \mathrm{C}$ at $3{ }^{\circ} \mathrm{C} / \mathrm{min}$. A deactivated fused silica loop of $1.0 \mathrm{~m} \times 0.10 \mathrm{~mm} d_{c}$ was used. $\mathrm{GC} \times \mathrm{GC}$ column set consisted of a ${ }^{1} \mathrm{D}$ SE52 column (95\% polydimethylsiloxane, $5 \%$ phenyl) $\left(30 \mathrm{~m} \times 0.25 \mathrm{~mm} d_{c}, 0.25 \mu \mathrm{m} d_{f}\right)$ coupled with a ${ }^{2}$ D OV1701 column (86\% polydimethylsiloxane, $7 \%$ phenyl, 7\% cyanopropyl $)\left(1 \mathrm{~m} \times 0.1 \mathrm{~mm} d_{c}, 0.10 \mu \mathrm{m}\right.$ $d_{f}$ ); columns were from MEGA (Legnano (Milan)-Italy). GC S/SL injector: $1 / 10$ split mode; temperature: $250{ }^{\circ} \mathrm{C}$; carrier gas: helium at a constant flow and initial head pressure $280 \mathrm{KPa}$; Oven programming: from $45{ }^{\circ} \mathrm{C}$ $(1 \mathrm{~min})$ to $260{ }^{\circ} \mathrm{C}(5 \mathrm{~min})$ at $2.5{ }^{\circ} \mathrm{C} / \mathrm{min}$. Data were acquired by Agilent-MSD Chem Station ver D.02.00.275 (Agilent Technologies, Little Falls, DE, USA) and processed using GC Image software, ver 2.5 (GC Image, LLC Lincoln NE, USA).

\section{GC-MS analysis of essential oils}

Essential oils were analyzed by GC-MS with a system consisting of an Agilent 6890 N GC unit coupled with a 5973A MS detector operating in EI mode at $70 \mathrm{eV}$ (Agilent, Little Falls, DE, USA). Transfer line was set at $280{ }^{\circ} \mathrm{C}$. A Standard Tune option was used with a scan range of $35-250 \mathrm{~m} / \mathrm{z}$. The GC column was a ZB-5MS Zebron (Phenomenex, Torrance, CA, US) (95\% polydimethylsiloxane, $5 \%$ phenyl $)\left(30 \mathrm{~m} \times 0.25 \mathrm{~mm} d_{c}\right.$, $\left.0.25 \mu \mathrm{m} d_{f}\right)$. GC S/SL injector: in splitless mode; temperature: $250{ }^{\circ} \mathrm{C}$; carrier gas: helium at a constant flow $1.0 \mathrm{~mL} / \mathrm{min}$; Oven programming: from $60{ }^{\circ} \mathrm{C}$ (51 min) to $270{ }^{\circ} \mathrm{C}(5 \mathrm{~min})$ at $3{ }^{\circ} \mathrm{C} / \mathrm{min}$.

\section{Microbiological media}

LB (10.0 g/L NaCl, $10.0 \mathrm{~g} / \mathrm{L}$ tryptone, $5.0 \mathrm{~g} / \mathrm{L}$ yeast extract, $15.0 \mathrm{~g} / \mathrm{L}$ agar), YEPD (10.0 g/L yeast extract, $20.0 \mathrm{~g} / \mathrm{L}$ peptone, $20.0 \mathrm{~g} / \mathrm{L}$ D-glucose, 20.0/g L agar) and NA (5.0 g/L tryptone, $3.0 \mathrm{~g} / \mathrm{L}$ beef extract, $15.0 \mathrm{~g} / \mathrm{L} \mathrm{NaCl}, 15.0 \mathrm{~g} / \mathrm{L}$ agar) solid media were used for isolation of gut microorganisms from both female and male individuals of $C$. herbacea. The chemically defined SRM medium $(1.0 \mathrm{~g} / \mathrm{L}$ $\mathrm{NH}_{4} \mathrm{H}_{2} \mathrm{PO}_{4}, 0.2 \mathrm{~g} / \mathrm{L} \mathrm{KCl}, 0.2 \mathrm{~g} / \mathrm{L} \mathrm{MgSO}_{4}, 1.0 \mathrm{~g} / \mathrm{L}$ glucose, $15.0 \mathrm{~g} / \mathrm{L}$ agar, when requested) was used as a base to formulate either SRM-0 medium (without glucose) or SRMoil medium by replacing glucose with an emulsion $M$. aquatica essential oil:DMSO (0.002\%:0.25\%, [v:v]) to test the bacterial growth in the presence of essential oil as sole carbon and energy source. LB, NA, Hickey-Tresner (HT) $(1.0 \mathrm{~g} / \mathrm{L}$ yeast extract, $1.0 \mathrm{~g} / \mathrm{L}$ beef extract, $2.0 \mathrm{~g} / \mathrm{L} \mathrm{N}-\mathrm{Z}$ amine A, $10.0 \mathrm{~g} / \mathrm{L}$ starch, $15.0 \mathrm{~g} / \mathrm{L}$ agar) and GYM $(4.0 \mathrm{~g} / \mathrm{L}$ glucose, $4.0 \mathrm{~g} / \mathrm{L}$ yeast extract, 10.0 malt extract, $2.0 \mathrm{~g} / \mathrm{L} \mathrm{CaCO} 3$, agar $15 \mathrm{~g} / \mathrm{L}$ ) solid media were used for microbiological assays.

\section{Isolation of the cultivable gut bacteria from C. herbacea female and male individuals}

Two insect pools (males and females), each consisting of 10 individuals, were placed in a sterile physiological solution $(0.9 \% \mathrm{NaCl})$. Each insect pool suspension was decanted and rinsed thrice with $10 \mathrm{~mL}$ sterile $0.9 \%(\mathrm{w} / \mathrm{v})$ $\mathrm{NaCl}$ solution. Then, the rinsed insect pool was treated with $3 \%(\mathrm{v} / \mathrm{v}) \mathrm{H}_{2} \mathrm{O}_{2}$ for $20 \mathrm{~s}$, and finally rinsed with $70 \%(\mathrm{v} / \mathrm{v})$ ethanol and rapidly flamed. The throat of each insect was cut with a sterile scalpel and the head was removed. Pressing on the paunch of the cut insects the total intestine was collected in $5 \mathrm{~mL}$ LB broth containing 2-3 g of sterile glass beads $(\phi 0.5 \mathrm{~mm})$, heavily vortexed for 4$5 \mathrm{~min}$ and left to elute overnight at $4{ }^{\circ} \mathrm{C}$. To remove gut debris, samples were centrifuged at $2000 \times \mathrm{g}$ for $1 \mathrm{~min}$. Then, 1:10 serial dilutions of the supernatant were transferred on the surface of LB, NA and YEPD solid media and plated. Samples were incubated under aerobic or microaerophilic condition for $24 \mathrm{~h}$ at $30{ }^{\circ} \mathrm{C}$. After this incubation time, a number of colonies with distinct morphology were picked up from each agar plate media and streaked onto fresh plates. Only plates with colony numbers ranging from 50 to 200 were used for isolation of pure cultures. Pure cultures were checked by microscopy, and stored either in above mentioned agar slants or in broth plus $20 \%(\mathrm{v} / \mathrm{v})$ glycerol at $-80{ }^{\circ} \mathrm{C}$.

\section{DNA procedures}

All gut bacteria (200 from females and 45 from males) were grown in $20 \mathrm{~mL}$ of the above-mentioned liquid 
media with rotary shaking to late logarithmic phase. After centrifugation at $2000 \times \mathrm{g}$ for $20 \mathrm{~min}$, pellets were re-suspended in $500 \mu \mathrm{L}$ of SET buffer $(75 \mathrm{mM} \mathrm{NaCl}$, $25 \mathrm{mM}$ EDTA, $20 \mathrm{mM}$ Tris- $\mathrm{HCl} \mathrm{pH}$ 7.5). Lysozyme was added at a final concentration of $1 \mathrm{mg} / \mathrm{mL}(\mathrm{w} / \mathrm{v})$, and samples were incubated at $37{ }^{\circ} \mathrm{C}$ for $1 \mathrm{~h}$. Then, sodium dodecyl sulphate (SDS) and proteinase $\mathrm{K}$ were added, respectively, at a final concentration of $1 \%(\mathrm{v} / \mathrm{v})$ and $0.5 \mathrm{mg} / \mathrm{mL}(\mathrm{w} / \mathrm{v})$ and samples were incubated at $55^{\circ} \mathrm{C}$ for $2 \mathrm{~h}$ in a water bath and periodically stirred. Total nucleic acids were extracted by phenol:chloroform:isoamylic alcohol $(25: 24: 1[\mathrm{v} / \mathrm{v} / \mathrm{v}])$ method according to standard procedures [107] and RNase A (final concentration $15 \mu \mathrm{g} / \mathrm{mL}$ ) was used to remove contaminant RNA. After the extraction, high-molecular weight DNA was used as template in polymerase chain reactions (PCRs) to amplify the repetitive extragenic palindromic (REP) or BOX regions [108] and the partial length of the 16S rRNA encoding-gene.

For culture-independent analysis, the total intestine from male and female individuals was removed as described above and homogenized in a sterile tube containing glass beads $(0.55 \mathrm{~mm}$ diameter) and $0.5 \mathrm{~mL} \mathrm{SET}$ buffer for 15 min using a sterile pestle. Total DNA was then extracted using standard phenol-chloroform and ethanol precipitation method [107].

\section{BOX-PCR genomic fingerprinting}

BOX-PCR genomic fingerprinting was done on all isolates as previously described [109] using the BOXA1-R primer (5'-CTACGGCAAGGCGACGCTGACG-3'). PCR products were separated on a $1 \%(\mathrm{w} / \mathrm{v})$ agarose gel in $1 \times$ TBE buffer [107]. This analysis led us to identify 16 different genomic patterns (10 from female and 6 from male individuals). In order to better characterize these 16 gut isolates, having a different BOX profile, molecular identification was performed.

\section{S rRNA gene sequencing and phylogenetic analysis}

Almost the entire $16 \mathrm{~S}$ rRNA gene (from nucleotide 20 to nucleotide 1488 of the corresponding E. coli sequence) was amplified and sequenced by using the primer pairs 16SE20-42-F/16SEB683-R (corresponding to E. coli positions 20 to 683) [109, 110], Com1-F/Com2-R (corresponding to E. coli positions 519 to 926) [111], and 16SEB785-F/16SEB1488-R (corresponding to E. coli positions 785 to 1488$)[109,110]$. These primer pairs amplified concatenated (and partially overlapping) DNA regions. PCR products were separated by agarose gel in $1 \times$ TAE buffer (40 mM Tris-acetate, $1 \mathrm{mM}$ EDTA, $\mathrm{pH}$ 8.0), recovered by using the Qiaex II Gel extraction kit (Qiagen) and sequenced by using the same primers pair utilized for the respective amplifications by MWG Biotech Customer Sequencing Service (Germany). The sequences of bacterial isolates were compared with those of their closely related reference strains present in EzTaxon-e server [112]. Multiple sequence alignments between each pair of sequences were performed with ClustalW program at the Kyoto University Bioinformatic Center (http://www.genome.jp/tools/clustalw/) as previously described [113]. Phylogenetic trees were constructed using the SeaView software [114] according to the neighbour-joining (NJ) [115], and Kimura's twoparameter algorithm [116]. Tree robustness was determined by bootstrap analysis based on 1,000 resamplings of data [117].

\section{Limited culture-independent analysis of gut bacteria}

16S rRNA gene sequences from gut communities of 3 male and 3 female individuals (biological triplicates) were separately amplified using bacterial broad-range primer pairs Com1-F and 16SEB1488-R (amplicon length, $969 \mathrm{bp}$ ) in standard PCR. The relative amounts of amplifiable Firmicutes, $\alpha$ - and $\gamma$-Proteobacteria $16 \mathrm{~S}$ rRNA gene sequences was determined by semiquantitative real-time PCR using phylum/subphylum specific primer pairs.

Primer design was based on a representative phylogenetic dataset derived from the quality-checked and aligned sequences of the SILVA rRNA database project [118] (http://www.arb-silva.de). Primer sequences and amplicon lengths are reported below.

For semi-quantitative real-time PCR, each reaction was run on a SmartCycler system (Cepheid) with SsoAdvanced Universal SYBR Green Supermix (BIORAD) and the following primer pairs: Firm934-F/ Firm1060-R (specific for Firmicutes 16S rRNA, amplicon length 126 bp) [119], Gamma877-F/Gamma1066-R (specific for $\gamma$-Proteobacteria 16S rRNA, amplicon length $189 \mathrm{bp}$ ) [119], and ADF681-F/ADF1362-R (specific for $\alpha$ Proteobacteria 16S rRNA, amplicon length $681 \mathrm{bp}$ ) [120]. Com1-F/16SEB1488-R primer pair was used as a control for normalization.

Real-time PCR samples were run under these conditions: $3 \mathrm{~min}$ at $94{ }^{\circ} \mathrm{C}, 30 \mathrm{~s}$ at $94{ }^{\circ} \mathrm{C}, 30 \mathrm{~s}$ at $55^{\circ} \mathrm{C}, 30 \mathrm{~s}$ at $72{ }^{\circ} \mathrm{C}$ for 35 cycles. Differences in cycle threshold $(\Delta \mathrm{Ct})$ values between samples from males and females with phylum/subphylum-specific primers were normalized to differences in $\Delta \mathrm{Ct}$ with control primers.

\section{Microbiological assays}

In order to determine whether any of the isolated gut bacterial strain could inhibit the growth of the others, microbiological assays were performed as follows. The bacterial strain that was assayed to detect antibiotic activity (referred to as "assayed bacterium" in Table 3) was grown until confluence on agar plates at $30{ }^{\circ} \mathrm{C}$ for $24 \mathrm{~h}$. After growth, by using a sterile metallic cylinder 
(diameter $1 \mathrm{~cm}$ ), agar disks with assayed bacteria were removed and positioned onto solid agar media (above mentioned) containing a suspension of the bacterium used to detect antibiotic activity (referred to as "tester bacterium" in Table 3) at a final concentration of 0.03 $\mathrm{OD}_{600 \mathrm{~nm}} / \mathrm{mL}$. All gut bacteria from males and females were both crossed as "assayed" and "tester" microorganisms in various combinations. In addition, the following reference strains were used as tester microorganisms: E. coli strain FB8 [62], S. enterica subsp. enterica serovar Typhimurium strain LT2 ATCC $700720^{\mathrm{T}}$ [63], S. aureus strain SA-1 [59], M. luteus strain ML-1 [60] and S. ambofaciens strain ATCC 23877 [61]. The rifamycin B producer Amycolatopsis mediterranei $\mathrm{S} 699$ was used as an antibiotic-producing control strain [121]. The following solid media were used: LB for the cultivation of all gut bacteria, E. coli strain FB8 and S. enterica subsp. enterica serovar Typhimurium strain LT2; NA for $S$. aureus strain SA-1 and $M$. luteus strain ML-1; HT for S. ambofaciens strain ATCC 23877; GYM for A. mediterranei S699. Each plate was incubated for $24 \mathrm{~h}$ at a different temperature depending of the tester bacterial strain utilized: $28{ }^{\circ} \mathrm{C}$ for S. ambofaciens strain ATCC 23877, $30{ }^{\circ} \mathrm{C}$ for all gut bacteria, $37{ }^{\circ} \mathrm{C}$ for E. coli strain FB8, S. Typhimurium strain LT2, S. aureus strain SA-1 and M. luteus strain ML-1. After this incubation time, a zone of growth inhibition can be seen around agar disk demonstrating the antibacterial activity of the assayed strain on tester microorganism. The diameters of the zones of growth inhibition were measured after subtracting the $1 \mathrm{~cm}$-diameter of the agar disk containing the assayed bacterium, and the mean \pm SD was calculated based on three independent experiments.

\section{Growth of gut bacteria on chemically defined media}

We evaluated the ability of gut bacteria to grow in the chemically defined SRM, SRM-0 (without glucose) or SRM-oil media by replacing glucose with DMSOdissolved $M$. aquatica essential oil (0.002\%:0.25\% [v:v]). Preliminary, the eventual side effect of dimethylsulfoxide (DMSO) on bacterial growth/survival was tested as previously described by Del Giudice et al. [100] with some modification. Briefly, log-phase bacterial cells grown without shaking at $30{ }^{\circ} \mathrm{C}$ were inoculated in $6 \mathrm{~mL}$ of SRM medium at a final concentration of about $1 \times 10^{5}$ cells $/ \mathrm{mL}$. DMSO was added to reach the desired final concentration and the mixture was incubated at $30{ }^{\circ} \mathrm{C}$ under rotary shaking. $0.1 \mathrm{~mL}$ of the culture samples were collected at different intervals of time $(24,30$ and $36 \mathrm{~h})$, diluted appropriately (1:10, 1:100, 1:1000 in SRM) and plated on SRM agar in order to determinate the bacterial titers. To evaluate the effect of $M$. aquatica essential oil on bacterial growth, the essential oil was dissolved in $0.25 \%(\mathrm{v} / \mathrm{v})$ DMSO, a suitable concentration with no inhibitory effect on the bacterial growth. No strain was able to grow when DMSO replaced glucose without essential oil.

\section{Growth of gut bacteria in the presence of M. aquatica essential oil}

We also tested the capability of the bacterial isolates to grow both individually and in community by using the $M$. aquatica essential oil as sole carbon (and energy) source and biotransform it. Bacterial strains were grown individually until to middle logarithmic phase in SRM medium at $30{ }^{\circ} \mathrm{C}$ with rotary shaking. After this incubation time, cells were centrifuged, washed twice, re-suspended in SRM-0 medium (without glucose) and plated at appropriate dilutions (1:10, 1:100, 1:1000 in SRM) on solid SRM medium supplemented with a $M$. aquatica essential oil:DMSO emulsion $(0.002 \%: 0.25 \%,[\mathrm{v} / \mathrm{v}])$. Then, the microorganisms that exhibited growth on solid SRM-oil medium, were individually inoculated into liquid SRM-oil medium until middle logarithmic phase at $30{ }^{\circ} \mathrm{C}$ for $48 \mathrm{~h}$ with rotary shaking in order to reach a mean value of 1.0 $\mathrm{OD}_{600 \mathrm{~nm}} / \mathrm{mL}$. Finally, a $0.1 \mathrm{~mL}$ aliquot of each previous individual growth was taken and used to inoculate two bacterial communities into liquid SRM-oil medium. One community contained gut isolates from females (CHF-B4, CHF-B16, CHF-B17, CHF-B26, CHF-B37, CHF-G5, CHFG14, CHF-PG1, CHF-PG3, CHF-PG4) and the other one containing those isolated from males (CHM-L11, CHML21, CHM-L22, CHM-N25, CHM-N28, CHM-N31). The two communities were incubated for about $40 \mathrm{~h}$ at $30{ }^{\circ} \mathrm{C}$. After this period, bacterial cells were discarded and supernatant was further purified through Millipore filter $(0.22 \mu \mathrm{m})$ before extraction (see below).

\section{SBSE-GC-MS profiling of bacterial metabolic transformations}

Strains were grown in SRM medium to late logarithmic growth (about $30 \mathrm{~h}$ ) at $28{ }^{\circ} \mathrm{C}$ with shaking. Bacteria were centrifuged, washed twice and re-suspended in SRM-0 at $\mathrm{OD}_{600}$ of 0.2 and incubated in $2 \mathrm{ml}$ SRM-0 medium supplemented with both $8.0 \mathrm{mM} \mathrm{L}$-glutamic acid, $20 \mu \mathrm{g} / \mathrm{ml}$ DMSO-dissolved $M$. aquatica essential oil for $40 \mathrm{~h}$ at $28{ }^{\circ} \mathrm{C}$. Then bacterial cells were spin down and supernatant was further purified by Millipore filter (pore size $0.22 \mu \mathrm{m}$ ) before extraction. Compounds biotransformed by bacteria were extracted by using SBSE by direct immersion and stirring of SBSE into the supernatants as previously described [100].

\section{5 rRNA GenBank Accession Numbers}

The 16S rDNA nucleotide sequences of the 16 bacterial isolates were deposited at GenBank with the following accession numbers: Serratia sp. CHF-B4 (KP325087), 
Serratia sp. CHF-B16 (KP325088), Serratia sp. CHFB17 (KP325089), Serratia sp. CHF-B26 (KP325090), Serratia sp. CHF-B37 (KP325091), Serratia sp. CHFG5 (KP325092), Pantoea sp. CHF-G14 (KP325093), Pseudomonas sp. CHF-PG1 (KP325094), Pseudomonas sp. CHF-PG3 (KP325095), Sphingomonas sp. CHF-PG4 (KP325096), Bacillus sp. CHM-L11 (KP325097), Bacillus sp. CHM-L21 (KP325098), Bacillus sp. CHM-L22 (KP325099), Pseudomonas sp. CHM-N25 (KP325100), Serratia sp. CHM-N28 (KP325101), Pseudomonas sp. CHM-N31 (KP325102).

\section{Statistical analysis}

In general all experiments were repeated at least three times. For chemical analyses, the experiments were repeated three times (biological replicates) with at least 15 plants and 30-50 insects for each experiment. Three technical replicates were run for each biological replicate. Fold change data are expressed as mean values, and standard deviations were generally less than $10 \%$ in all determinations. Analysis of variance (ANOVA) and the Tukey test were used to assess difference between samples.

\section{Additional files}

Additional file 1: Figure S1. BOX-PCR genomic fingerprinting of the gut bacterial isolates from $A$ ) females and $B$ ) males of $C$. herbacea using BOXA1-R primer. M, 1 Kb DNA Ladder Invitrogen; 1, CHF-B26; 2, CHF-G5; 3, CHF-B37; 4, CHF-PG1; 5, CHF-PG3; 6, CHF-B4; 7, CHF-PG4; 8, CHF-G14; 9 , CHFB16; 10, CHF-B17; 11, CHM-L11; 12, CHM-L21; 13, CHM-L22; 14, CHMN25; 15, CHM-N28; 16, CHM-N31. Figure S2. Examples of antibacterial activities (demonstrated by halo of growth inhibition around assayed microorganism). A, Assayed bacteria: CHF-B4, CHF-B16, CHF-B17, CHF-B26, CHFB37, CHF-G5; Tester bacterium: CHM-L11. B, Assayed bacteria: CHF-B4, CHF-B16, CHF-B17, CHF-B26, CHF-B37, CHF-G5; Tester bacterium: CHML11. C, Assayed bacterium: A. mediterranei S699; Tester bacteria (from left to right): CHM-L11, CHM-L21 and CHM-L22. For details refer to the Methods section. (PDF $1546 \mathrm{~kb}$ )

Additional file 2: File S1. Relative abundance of Firmicutes, $a$ - and $\gamma^{-}$ Proteobacteria $16 \mathrm{~S}$ rRNA gene sequences in C. herbacea male and female guts as determined by real-time PCR using phylum/subphylum specific primer pairs. The file reports raw data (yellow background), data analysis and statistical processing from real-time PCR experiments. Samples \#1, \#2 and \#3 represent biological triplicates. (XLSX $47 \mathrm{~kb}$ )

\footnotetext{
Abbreviations

ANOVA: Analysis of variance; CFU: Colony-forming units; DMSO: Dimethylsulfoxide; DVB/CAR/PDMS: Divinylbenzene/Carboxen/ Polydimethylsiloxane; EDTA: Ethylenediaminetetraacetic Acid; GC-MS: Monodimensional gas chromatography-mass spectrometry; GCXGC-MS: Twodimensional gas chromatography-mass spectrometry; GYM: Glucose Yeast Malt; HS-SPME: Headspace solid-phase microextraction; HT: Hickey-Tresner; ISTD: Internal Standard; LB: Luria-Bertani; MVOCs: Microbial volatile organic compounds; NA: Nutrient Agar; NJ: Neighbour-joining; REP: Repetitive extragenic palindromic; SBSE: Stir Bar Sorptive Extraction; SD: Standard deviation; SDS: Sodium dodecyl sulphate; SET: Sodium EDTA Tris-HCl; TAE: Tris Acetic Acid EDTA; TBE: Tris Boric Acid EDTA; YEPD: Yeast Extract Peptone Dextrose; $\Delta \mathrm{Ct}$ : Cycle threshold
}

\section{Acknowledgments}

We thank Fulvia Stanzione for proof editing support and Mariarosaria Aletta for bibliographic support. We also thank Dr. Alessio Aprile for technical support in real-time PCR technique, and Dr. Marco Di Salvo for statistical support.

\section{Funding}

The research was supported by Compagnia di San Paolo special grant "iniziativa" to L. Del Giudice. P. Pontieri was supported by a postdoctoral grant from the Istituto Banco di Napoli - Fondazione.

\section{Availability of data and materials}

Raw data and/or datasets generated during and/or analyzed during the current study are available from the corresponding authors on reasonable request. Several supportive datasets are presented in the section "Additional files".

\section{Authors' contributions}

Conceived and designed the experiments: LDG, CB, MEM, PA. Performed the experiments: GP, CC, SMT, DV, AC, PP, CNK, SAZ. Analyzed the data: LDG, CC, PR, CB, GP, MEM, PA. Wrote the paper: GP, MEM, PA. All authors read and approved the final manuscript.

\section{Competing interest}

The authors declare that they have no competing interest.

\section{Consent for publication}

Not applicable.

\section{Ethics approval and consent to participate} Not applicable.

\section{Author details}

1Department of Biological and Environmental Sciences and Technologies, University of Salento, via Monteroni 165, 73100 Lecce, Italy. ${ }^{2}$ Dipartimento di Scienza e Tecnologia del Farmaco, Università di Torino, Via Pietro Giuria nº, 10125 Torino, Italy. ${ }^{3}$ Dipartimento di Biologia, Sezione di Igiene, Institute of Biosciences and Bioresources-UOS Portici (IBBR-UOS Portici), CNR, Portici (NA) C/o, 80134 Naples, Italy. ${ }^{4}$ Dipartimento di Scienze della Vita e Biologia dei Sistemi, Università di Torino, Via Quarello 15/A, 10135 Torino, Italy. ${ }^{5}$ Research and Innovation Centre Genomics and Biology of Fruit Crop Department, Fondazione Edmund Mach (FEM), Istituto Agrario San Michele (IASMA), Via Mach 1, 38010 San Michele all'Adige, TN, Italy. ${ }^{6}$ Department of Natural Sciences, University of Maryland Eastern Shore, 1117 Trigg Hall, Princess Anne 21853, MD, USA.

Received: 3 March 2016 Accepted: 24 January 2017

Published online: 02 March 2017

References

1. Chen MS. Inducible direct plant defense against insect herbivores: a review. Insect Sci. 2008;15:101-14.

2. Kessler A, Baldwin IT. Defensive function of herbivore-induced plant volatile emissions in nature. Science. 2001;291:2142-3.

3. Van Poecke RMP, Dicke M. Indirect defence of plants against herbivores: using Arabidopsis thaliana as a model plant. Plant Biol. 2004;6:387-401.

4. Howe GA, Jander G. Plant immunity to insect herbivores. Annu Rev Plant Physiol Plant Mol Biol. 2008:59:41-66.

5. Maffei ME. Sites of synthesis, biochemistry and functional role of plant volatiles. S Afr J Bot. 2010;76:612-31.

6. Dicke M, Loreto F. Induced plant volatiles: from genes to climate change. Trends Plant Sci. 2010;15:115-7.

7. Dicke M, Baldwin IT. The evolutionary context for herbivore-induced plant volatiles: beyond the 'cry for help'. Trends Plant Sci. 2010;15:167-75.

8. Scriber JM. Evolution of insect-plant relationships: chemical constraints, coadaptation, and concordance of insect/plant traits. Entomol Exper Appl. 2002;104:217-35.

9. Farrell BD, Mitter C. Adaptive radiation in insects and plants-time and opportunity. Amer Zool. 1994;34:57-69.

10. Zebelo SA, Bertea CM, Bossi S, Occhipinti A, Gnavi G, Maffei ME. Chrysolina herbacea modulates terpenoid biosynthesis of Mentha aquatica L. PLoS One. $2011 ; 6: \mathrm{e} 17195$. 
11. Cordero C, Zebelo SA, Gnavi G, Griglione A, Bicchi C, Maffei ME, et al. HSSPME-GC $\times$ GC-qMS volatile metabolite profiling of Chrysolina herbacea frass and Mentha spp. leaves. Anal Bioanal Chem. 2011;402:1941-52.

12. Lawrence BM. Mint: the genus Mentha. Boca Raton: CRC; 2007.

13. Maffei ME, Sacco T. Chemical and morphometrical comparison between 2 peppermint notomorphs. Planta Med. 1987;53:214-6.

14. Maffei ME. A chemotype of Mentha longifolia (L.) Hudson particularly rich in piperitenone oxide. Flavour Fragr J. 1988;3:23-6.

15. Maffei ME, Chialva F, Sacco T. Glandular trichomes and essential oil in developing peppermint leaves. I. Variation in peltate trichome number and terpene distribution within leaves. New Phytol. 1989;111:707-16.

16. Kanchiswamy CN, Malnoy M, Maffei ME. Chemical diversity of microbial volatiles and their potential for plant growth and productivity. Front Plant Sci 2015; 6. doi:10.3389/fpls.2015.00151

17. Abraham WR, Hoffmann HMR, Kieslich K, Reng G, Stumpf B. Microbial transformations of some monoterpenoids and sesquiterpenoids. Ciba Found Symp. 1985;111:146-60.

18. Duetz WA, Fjallman AHM, Ren SY, Jourdat C, Witholt B. Biotransformation of D-limonene to (+) trans-carveol by toluene-grown Rhodococcus opacus PWD4 cells. Appl Environ Microbiol. 2001;67:2829-32.

19. Duetz WA, Bouwmeester $\mathrm{H}$, van Beilen JB, Witholt B. Biotransformation of limonene by bacteria, fungi, yeasts, and plants. Appl Microbiol Biotechnol. 2003;61:269-77.

20. Bicas JL, Fontanille P, Pastore GM, Larroche C. Characterization of monoterpene biotransformation in two pseudomonads. J Appl Microbiol. 2008;105:1991-2001.

21. Krings U, Berger RG. Terpene bioconversion-how does its future look? Nat Prod Comm. 2010;5:1507-22.

22. Dillon RJ, Dillon VM. The gut bacteria of insects: non-pathogenic interactions. Annu Rev Entomol. 2004;49:71-92.

23. Hammer TJ, Bowers MD. Gut microbes may facilitate insect herbivory of chemically defended plants. Oecologia. 2015;179:1-14.

24. Ceja-Navarro JA, Vega FE, Karaoz U, Hao Z, Jenkins S, Lim HC, Kosina P, Infante F, Northen TR, Brodie EL. Gut microbiota mediate caffeine detoxification in the primary insect pest of coffee. Nat Commun. 2015:6:7618.

25. Boone CK, Keefover-Ring K, Mapes AC, Adams AS, Bohlmann J, Raffa KF. 2013. Bacteria associated with a tree-killing insect reduce concentrations of plant defense compounds. J Chem Ecol. 2013;39:1003-6.

26. Welte CU, de Graaf RM, van den Bosch TJ, Op den Camp HJ, van Dam NM, Jetten MS. Plasmids from the gut microbiome of cabbage root fly larvae encode SaxA that catalyses the conversion of the plant toxin 2-phenylethyl isothiocyanate. Environ Microbiol. 2016;18:1379-90.

27. Brune A, Miambi E, Breznak JA. Roles of oxygen and the intestinal microflora in the metabolism of lignin-derived phenylpropanoids and other monoaromatic compounds by termites. Appl Environ Microbiol. 1995:61:2688-95.

28. Croteau R, Alonso WR, Koepp AE, Johnson MA. Biosynthesis of monoterpenes: partial purification, characterization, and mechanism of action of 1,8-cineole synthase. Arch Biochem Biophys. 1994;309:184-92.

29. ObengOfori D, Reichmuth $\mathrm{CH}$, Bekele J, Hassanali A. Biological activity of 1,8 cineole, a major component of essential oil of Ocimum kenyense (Ayobangira) against stored product beetles. J Appl Entomol. 1997;121:237-43.

30. Schmidt S, Walter GH, Moore CJ. Host plant adaptations in myrtaceous feeding Pergid sawflies: essential oils and the morphology and behaviour of Pergagrapta larvae (Hymenoptera, Symphyta, Pergidae). Biol Linn Soc. 2000;70:15-26.

31. Southwell IA, Russell MF, Maddox CDA, Wheeler GS. Differential metabolism of 1,8-cineole in insects. J Chem Ecol. 2003;29:83-94

32. Carman RM, Klika KD. Partially racemic compounds as brushtail possum urinary metabolites. Austr J Chem. 1992:45:651-7.

33. Southwell IA, Maddox CDA, Zalucki MP. Metabolism of 1,8-cineole in tea tree (Melaleuca alternifolia and Melaleuca linariifolia) by pyrgo beetle (Paropsisterna tigrina). J Chem Ecol. 1995;21:439-53.

34. Fletcher MT, Lowe LM, Kitching W, Konig WA. Chemistry of Leichhardt's grasshopper, Petasida ephippigera, and its host plants, Pityrodia jamesii, P. ternifolia, and P. pungens. J Chem Ecol. 2000;26:2275-90.

35. Kanchiswamy CN, Malnoy M, Maffei ME. Bioprospecting bacterial and fungal volatiles for sustainable agriculture. Trends Plant Sci. 2015;20:206-11.

36. Zebelo SA, Maffei ME. Role of early signalling events in plant-insect interactions. J Exp Bot. 2015;66:435-48.
37. Maffei ME, Arimura Gl, Mithoefer A. Natural elicitors, effectors and modulators of plant responses. Nat Prod Rep. 2012;29:1288-303.

38. Arimura G, Ozawa R, Maffei ME. Recent advances in plant early signaling in response to herbivory. Int J Mol Sci. 2011;12:3723-39.

39. Louws FJ, Fulbright DW, Stephens $C T$, de Bruijn FJ. Specific genomic fingerprints of phytopathogenic Xanthomonas and Pseudomonas pathovars and strains generated with repetitive sequences and PCR. Appl Environ Microbiol. 1994;60:2286-95.

40. Koeuth T, Versalovic J, Lupski JR. Differential subsequence conservation of interspersed repetitive Streptococcus pneumoniae BOX elements in diverse bacteria. Genome Res. 1995;5:408-18.

41. Berg G, Krechel A, Ditz M, Sikora RA, Ulrich A, Hallmann J. Endophytic and ectophytic potato-associated bacterial communities differ in structure and antagonistic function against plant pathogenic fungi. FEMS Microbiol Ecol. 2005;51:215-29.

42. Ajithkumar B, Ajithkumar VP, Iriye R, Doi Y, Sakai T. Spore-forming Serratia marcescens subsp. sakuensis subsp. nov., isolated from a domestic wastewater treatment tank. Int J Syst Evol Microbiol. 2003;53:253-8.

43. Bizio B. Lettera di Bartolomeo Bizio al chiarissimo canonico Angelo Bellani sopra il fenomeno della polenta porporina. Bibl Ital G Lett Sci Art VIII. 1823;30:275-95.

44. Bascomb S, Lapage SP, Willcox WR, Curtis MA. Numerical classification of the tribe Klebsielleae. J Gen Microbiol. 1971;66:279-95.

45. Brady CL, Venter SN, Cleenwerck I, Engelbeen K, Vancanneyt M, Swings J, et al. Pantoea vagans sp. nov., Pantoea eucalypti sp. nov., Pantoea deleyi sp. nov. and Pantoea anthophila sp. nov. Int J Syst Evol Microbiol. 2009;59:2339-45.

46. Hauser E, Kampfer P, Busse HJ. Pseudomonas psychrotolerans sp. nov. Int J Syst Evol Microbiol. 2004;54:1633-7.

47. Lee $\mathrm{M}$, Chandler AC. A study of the nature, growth and control of bacteria in cutting compounds. J Bacteriol. 1941;41:373-86.

48. Gardan L, Bella P, Meyer JM, Christen R, Rott P, Achouak W, et al. Pseudomonas salomonii sp. nov., pathogenic on garlic, and Pseudomonas palleroniana sp. nov., isolated from rice. Int J Syst Evol Microbiol. 2002:52:2065-74.

49. Kampfer $P$, Meurer U, Esser M, Hirsch T, Busse HJ. Sphingomonas pseudosanguinis sp. nov., isolated from the water reservoir of an air humidifier. Int J Syst Evol Microbiol. 2007;57:1342-5.

50. Frankland GC, Frankland PF. Studies on some new microorganisms obtained from air. Philos Trans Roy Soc B. 1887;178:257-87.

51. Cohn F. Untersuchungen über Bakterien. Beitrage zur Biologie der Pflanzen. 1872;1:127-224

52. Berliner E. Über die Schlaffsucht der Mehlmottenraupe (Ephestia kühniella Zell) und ihren Erreger Bacillus thuringiensis n sp. Zeitschrift fur angewandte Entomologie Berlin. 1915;2:29-56.

53. Jimènez $G$, Urdiain M, Cifuentes A, Lopez-Lopez A, Blanch AR, Tamames J, et al. Description of Bacillus toyonensis sp. nov., a novel species of the Bacillus cereus group, and pairwise genome comparisons of the species of the group by means of ANI calculations. Syst Appl Microbiol. 2013;36:383-91.

54. Flügge $\mathrm{KGFW}$, Flügge $\mathrm{C}$. Die Mikroorganismen : mit besonderer Berücksichtigung der Aetiologie der Infektionskrankheiten. Vogel, Leipzig: F.C.W; 1886.

55. Nakamura LK. Bacillus pseudomycoides sp. nov. Int J Syst Bacteriol. 1998:48:1031-5.

56. Lechner S, Mayr R, Francis KP, Prüss BM, Kaplan T, Wiessner-Gunkel E, et al. Bacillus weihenstephanensis sp. nov. is a new psychrotolerant species of the Bacillus cereus group. Int J Syst Bacteriol. 1998;48:1373-82.

57. Guinebretière MH, Auger S, Galleron N, Contzen M, De Sarrau B, De Buyser ML, et al. Bacillus cytotoxicus sp. nov. is a new thermotolerant species of the Bacillus cereus group occasionally associated with food poisoning. Int J Syst Evol Microbiol. 2013;63:31-40.

58. Werner W. Botanische Beschreibung haufiger am Buttersaureabbau beteiligter sporenbildender Bakterienspezies. Zentralbl Bakteriol Parasitenkd Infektionskr Hyg Abt. 1933;2(81):446-75.

59. Lee JC, Michon F, Perez NE, Hopkins CA, Pier GB. Chemical characterization and immunogenicity of capsular polysaccharide isolated from mucoid Staphylococcus aureus. Infect Immun. 1987;55:2191-7.

60. Tittle TV, Majo JA, Spitzer WP. Synthesis of DNA by Micrococcus luteus is resistant to 6-(p-hydroxyphenylazo)uracil. Can J Microbiol. 1980;26:640-2.

61. Cosar C, Ninet L, Pinnert-Sindico S, Preud'Homme J. Trypanocide action of an antibiotic produced by a Streptomyces. CR Hebd Seances Acad Sci. 1952;234:1498-9.

62. Kasai T. Regulation of the expression of the histidine operon in Salmonella typhimurium. Nature. 1974;49:523-7. 
63. Tindall BJ, Grimont PAD, Garrity GM, Euzèby JP. Nomenclature and taxonomy of the genus Salmonella. Int J Syst Evol Microbiol. 2005;55:521-4.

64. Genta FA, Dillon RJ, Terra WR, Ferreira C. Potential role for gut microbiota in cell wall digestion and glucoside detoxification in Tenebrio molitor larvae. J Insect Physiol. 2006;52:593-601.

65. Feldhaar $\mathrm{H}$. Bacterial symbionts as mediators of ecologically important traits of insect hosts. Ecol Entomol. 2011;36:533-43.

66. Ferrari J, Vavre F. Bacterial symbionts in insects or the story of communities affecting communities. Philos Trans R Soc B Biol Sci. 2011;366:1389-400.

67. Hurst GD, Werren $\mathrm{JH}$. The role of selfish genetic elements in eukaryotic evolution. Nat Rev Genet. 2001;2:597-606.

68. Braendle C, Miura T, Bickel R, Shingleton AW, Kambhampati S, Stern DL. Developmental origin and evolution of bacteriocytes in the aphid-Buchnera symbiosis. PLoS Biol. 2003;1:E21

69. Koropatnick TA, Engle JT, Apicella MA, Stabb EV, Goldman WE, McFall-Ngai MJ. Microbial factor-mediated development in a host-bacterial mutualism. Science. 2004:306:1186-8.

70. Backhed F, Ley RE, Sonnenburg JL, Peterson DA, Gordon Jl. Host-bacterial mutualism in the human intestine. Science. 2005:307:1915-20.

71. Baumann P. Biology of bacteriocyte-associated endosymbionts of plant sapsucking insects. Annu Rev Microbiol. 2005;59:55-89.

72. Macdonald TT, Monteleone G. Immunity, inflammation, and allergy in the gut. Science. 2005;307:1920-5.

73. Douglas AE. The microbial dimension in insect nutritional ecology. Funct Ecol. 2009;23:38-47.

74. Reichenbach SE, Tian X, Tao QP, Ledford EB, Wu ZP, Fiehn O. Informatics for cross-sample analysis with comprehensive two-dimensional gas chromatography and high-resolution mass spectrometry (GCXGC-HRMS). Talanta. 2011;83:1279-88.

75. Reichenbach SE, Tian X, Boateng AA, Mullen CA, Cordero C, Tao QP. Reliable peak selection for multisample analysis with comprehensive two-dimensional chromatography. Anal Chem. 2013;85:4974-81.

76. Bressanello D, Liberto E, Collino M, Reichenbach SE, Benetti E, Chiazza F, et al. Urinary metabolic fingerprinting of mice with diet-induced metabolic derangements by parallel dual secondary column-dual detection twodimensional comprehensive gas chromatography. J Chromatogr A 2014;1361:265-76.

77. Cordero C, Zebelo SA, Gnavi G, Griglione A, Bicchi C, Maffei ME, et al. HSSPME-GCXGC-qMS volatile metabolite profiling of Chrysolina herbacea frass and Mentha spp. leaves. Anal Bioanal Chem. 2012;402:1941-52.

78. Reichenbach SE, Tian X, Cordero C, Tao Q. Features for non-targeted crosssample analysis with comprehensive two-dimensional chromatography. J Chromatogr A. 2012;1226:140-8.

79. Cordero C, Liberto E, Bicchi C, Rubiolo P, Reichenbach SE, Tian X, et al. Targeted and non-targeted approaches for complex natural sample profiling by GCxGC-gMS. Chromatogr Sci. 2010;48:251-61.

80. Cordero C, Liberto E, Bicchi C, Rubiolo P, Schieberle P, Reichenbach SE, et al. Profiling food volatiles by comprehensive two-dimensional gas chromatography coupled with mass spectrometry: Advanced fingerprinting approaches for comparative analysis of the volatile fraction of roasted hazelnuts (Corylus avellana L.) from different origins. J Chromatogr A. 2010;1217:5848-58.

81. Grimont F, Grimont PAD. The genus Serratia. Proc Natl Acad Sci U S A. 2006;6:219-44

82. Iverson $\mathrm{KL}$, Bromel MC, Anderson AW, Freeman TP. Bacterial symbionts in the sugar beet rootmaggot, Tetanops myopaeformis (von Röder). Appl Environ Microbiol. 1984:47:22-7.

83. Bucher GE. Potential bacterial pathogens of insects and their characteristics. J Insect Pathol. 1960;2:172-95.

84. Stephens JM. Bactericidal activity of hemolymph of some normal insects. J Insect Pathol. 1963;5:61-5.

85. Kushner DJ, Harvey GT. Antibacterial substances in leaves: their possible role in insect resistance to disease. J Insect Pathol. 1962;4:155-84.

86. Kaska M. The toxicity of extracellular proteases of the bacterium Serratia marcescens for larvae of greater wax moth. Galleria mellonella J Invertebr Pathol. 1976;27:271.

87. Lysenko O. Chitinase of Serratia marcescens and its toxicity to insects. J Invertebr Pathol. 1976;27:385-6.

88. Aylward FO, Suen G, Biedermann PHW, Adams AS, Scott JJ, Malfatti SA, et al. Convergent bacterial microbiotas in the fungal agricultural systems of insects. MBio. 2014;5(6):e02077-14. doi:10.1128/mBio.02077-14.
89. van der Hoeven R, Betrabet G, Forst S. Characterization of the gut bacterial community in Manduca sexta and effect of antibiotics on bacterial diversity and nematode reproduction. FEMS Microbiol Lett. 2008;286:249-56.

90. Djadid ND, Jazayeri H, Raz A, Favia G, Ricci I, Zakeri S. Identification of the midgut microbiota of An. stephensi and An. maculipennis for their application as a paratransgenic tool against malaria. PLoS ONE. 2012;6:e28484.

91. Gayatri Priya N, Ojha A, Kajla MK, Raj A, Rajagopal R. Host plant induced variation in gut bacteria of Helicoverpa armigera. PLoS One. 2012;7:e30768.

92. Rogers EE, Backus EA. Anterior foregut microbiota of the glassy-winged sharpshooter explored using deep 165 rRNA gene sequencing from individual insects. PLoS One. 2014;9:e106215.

93. Roh JY, Choi JY, Li MS, Jin BR, Je YH. Bacillus thuringiensis as a specific, safe, and effective tool for insect pest control. J Microbiol Biotechnol. 2007; 17:547-59.

94. Vilain S, Luo Y, Hildreth MB, Brozel VS. Analysis of the life cycle of the soil saprophyte Bacillus cereus in liquid soil extract and in soil. Appl Environ Microbiol. 2006:72:4970-7.

95. Wood WF, Palmer TM, Stanton ML. A comparison of volatiles in mandibular glands from three Crematogaster ant symbionts of the whistling thorn acacia. Biochem Syst Ecol. 2002;30:217-22.

96. El-Sayed AM. The Pherobase: Database of Pheromones and Semiochemicals. http://www.pherobase.com. Accessed 09 Feb 2016.

97. Francis $F$, Vandermoten $S$, Verheggen $F$, Lognay $G$, Haubruge $E$. Is the (E)- $\beta$ farnesene only volatile terpenoid in aphids? J Appl Entomol. 2005;129:6-11.

98. Do Nascimento RR, Billen J, Sant'Ana AEG, Morgan ED, Harada AY. Pygidial gland of Azteca NR. bicolor and Azteca chartifex: morphology and chemical identification of volatile components. J Chem Ecol. 1998;24:1629-37.

99. Honda K, Hayashi N. Chemical nature of larval osmeterial secretions of papilionid butterflies in the genera Parnassius, Sericinus and Pachliopta. J Chem Ecol. 1995;21:859-67.

100. Del Giudice L, Massardo DR, Pontieri P, Bertea CM, Mombello D, Carata E, et al. The microbial community of Vetiver root and its involvement into essential oil biogenesis. Environ Microbiol. 2008;10:2824-41.

101. Viano J, Gaydou E, Smadja J. Sur la presence des bacteries intracellulaires dans les racines du Vetiveria zizanioides (L.) Staph. Rev Cytol Biol Veget Bot. 1991;14:65-70.

102. Adams RP, Habte M, Park S, Dafforn MR. Preliminary comparison of vetiver root essential oils from cleansed (bacteria- and fungus-free) versus noncleansed (normal) vetiver plants. Biochem Syst Ecol. 2004;32:1137-44.

103. Banchio E, Xie X, Zhang H, Pare PW. Soil bacteria elevate essential oil accumulation and emissions in sweet basil. J Agric Food Chem. 2009;57:653-7.

104. Alifano P, Talà A. Microbes at work in perfumery: odorous compounds from free-living and symbiotic bacteria living on plants and humans. H\&PC Today Fragrances. 2010;5:20-9.

105. Alifano P, Del Giudice L, Talà A, De Stefano M, Maffei ME. Microbes at work in perfumery: the microbial community of Vetiver root and its involvement in essential oil biogenesis. Flavour Fragr J. 2010;5:121-2.

106. Bicchi C, Maffei ME. The plant volatilome: methods of analysis. In: Normanly J, editor. High throughput phenotyping in plants: methods and protocols. Totowa, NJ: Methods in molecular biology. Humana Press; 2012. p. 289-310.

107. Sambrook J, Russell D. Molecular Cloning: a Laboratory Manual. 3rd ed. Cold Spring Harbor, New York: Cold Spring Harbor Laboratory Press; 2001.

108. Versalovic JSM, De Bruijn FJ, Lupski JR. Genomic fingerprinting of bacteria using repetitive sequence-based polymerase chain reaction. Methods Mol Cell Biol. 1994;5:25-40.

109. Di Giacomo M, Paolino M, Silvestro D, Vigliotta G, Imperi F, Visca P, et al. Microbial community structure and dynamics of dark fire-cured tobacco fermentation. Appl Environ Microbiol. 2007;73:825-37.

110. Vigliotta G, Nutricati E, Carata E, Tredici SM, De Stefano M, Pontieri P, et al. Clonothrix fusca Roze 1896 a filamentous, sheathed, methanotrophic gamma-proteobacterium. Appl Environ Microbiol. 2007;73:3556-65.

111. Lane DJ, Pace B, Olsen GJ, Stahl DA, Sogin ML, Pace NR. Rapid determination of $16 \mathrm{~S}$ ribosomal RNA sequences for phylogenetic analyses. Proc Natl Acad Sci U S A. 1985;82:6955-9.

112. Kim OS, Cho YJ, Lee $K$, Yoon SH, Kim M, Na H, et al. Introducing EzTaxon: a prokaryotic $16 \mathrm{~S}$ rRNA Gene sequence database with phylotypes that represent uncultured species. Int J Syst Evol Microbiol. 2012;62:716-21.

113. Talà A, Lenucci MS, Gaballo A, Durante M, Tredici SM, Debowles DA, et al. Sphingomonas cynarae sp. nov., a proteobacterium that produces an unusual type of sphingan. Int J Syst Evol Microbiol. 2013;63:72-9. 
114. Gouy M, Guindon S, Gascuel O. SeaView Version 4: a multiplatform graphical user interface for sequence alignment and phylogenetic tree building. Mol Biol Evol. 2010;27:221-4.

115. Saitou N, Nei M. The neighbour-joining method: a new method for reconstructing phylogenetic trees. Mol Biol Evol. 1987;4:406-25.

116. Kimura M. A simple method for estimating evolutionary rates of base substitutions through comparative studies of nucleotide sequences. J Mol Evol. 1980;16:111-20.

117. Brown JK. Bootstrap hypothesis tests for evolutionary trees and other dendrograms. Proc Natl Acad Sci U S A. 1994;91:12293-7.

118. Quast C, Pruesse E, Yilmaz P, Gerken J, Schweer T, Yarza P, et al. The SILVA ribosomal RNA gene database project: improved data processing and webbased tools. Nucl Acids Res. 2013;41:590-6.

119. Yang Y-W, Chen M-K, Yang B-A, Huang X-J, Zhang X-R, He L-Q, et al. Use of $16 S$ rRNA gene-targeted group-specific primers for real-time PCR analysis of predominant bacteria in mouse feces. Appl Environ Microbiol. 2015;81:6749-56.

120. Blackwood CB, Oaks A, Buyer JS. Phylum- and class-specific PCR primers for general microbial community analysis. Appl Environ Microbiol. 2005;71:6193-8.

121. Peano C, Damiano F, Forcato M, Pietrelli A, Palumbo C, Corti G, et al. Comparative genomics revealed key molecular targets to rapidly convert a reference rifamycin-producing bacterial strain into an overproducer by genetic engineering. Metab Eng. 2014:26:1-16.

\section{Submit your next manuscript to BioMed Central} and we will help you at every step:

- We accept pre-submission inquiries

- Our selector tool helps you to find the most relevant journal

- We provide round the clock customer support

- Convenient online submission

- Thorough peer review

- Inclusion in PubMed and all major indexing services

- Maximum visibility for your research

Submit your manuscript at www.biomedcentral.com/submit 